doi: 10.32620/oikit.2020.90.01

УДК 629.735.45.025-027.3:

А.Г. Гребеников, И.В. Малков, $620.22-419$

С. П. Светличный, А.В. Лоленко ,

А.И. Кривобок, В.А. Урбанович,

Н.И. Москаленко

\title{
Анализ характеристик напряженно-деформированного состояния комлевой части лопасти несущего винта вертолета
}

\author{
Национальный аэрокосмический университет им. Н. Е. Жуковского \\ «Харьковский авиационный институт» \\ * $A O$ «Momop Cuч»
}

\begin{abstract}
Представлена комлевая часть лопасти несущего винта (НВ) вертолета. Разработана геометрическая модель рассчитываемого соединения с помощью системы CATIA V5. C помощью системы ANSYS разработана конечно-элементная модель комлевой части лопасти несущего винта, проведен расчет и анализ характеристик полученных результатов. Для описания отклика материалов на внешнее воздействие применяли модель упруго-деформируемого изотропного тела с заданием соответствующих упругих констант материала. Рассмотрен случай нагружения болтового соединения центробежной силой, возникающей при вращении лопасти. Для моделирования контактного взаимодействия принимали обобщенную модель контактного взаимодействия типа «поверхность в поверхность». Анализ результатов расчета включает в себя определение реакций в точках крепления, величин максимальных перемещений элементов конструкции и напряжений в зонах концентрации напряжений. В ходе расчета определены реакции в точках крепления наконечника по отверстиям в проушинах. Проанализирован характер деформирования болтового соединения в целом и ее отдельных элементов. Проведена оценка суммарных перемещений и компонентов перемещений. Для оценки статической и усталостной прочности элементов болтового соединения наконечника с лонжероном лопасти проанализированы напряжения в силовых элементах по типовым концентраторам. При оценке статической прочности анализировали распределение эквивалентных напряжений по Мизесу. Проанализировано распределение напряжений в зоне отверстий по рядам, начиная от корневого сечения в сторону увеличения координаты Y. Максимальные значения напряжений по Мизесу для типовых зон концентрации напряжений сравнивали с пределом прочности материала элемента конструкции. Для оценки усталостной прочности анализировали распределение главных растягивающих напряжений в силовых элементах по типовым концентраторам напряжений. Максимальные значения этих напряжений сравнивали с пределом выносливости материала конструктивного элемента.
\end{abstract}

Ключевые слова: лопасть несущего винта, комлевая часть, геометрическая модель, конечно-элементная модель, болтовое соединение, модель контактного взаимодействия, статическая прочность, усталостная прочность.

\section{Введение}

Процесс конструирования лопасти заключается в определении массовых, жесткостных и геометрических характеристик основных ее конструктивных элементов. При этом приходится решать сложные конструктивнотехнологические задачи, учитывая противоречивые требования, и прежде всего - требования обеспечения высокой усталостной прочности и ресурса [1]. Кроме того, при создании конструкции лопасти необходимо также стремиться к 
снижению ее массы, поскольку она определяет величину центробежной силы, действующей на лопасть и втулку несущего винта. Однако существует ряд ограничений: по массовой характеристике, по величине махового движения, по минимально осуществимым с точки зрения технологии размерам деталей.

Целью данной работы является разработка метода анализа влияния конструктивно-технологических параметров на характеристики напряженнодеформированного состояния элементов болтового соединения наконечника и лонжерона лопасти несущего винта вертолета в случае еe нагружения центробежной силой, возникающей при вращении лопасти.

\section{Постановка задачи}

Уравнение движения вертолета (рис. 1) имеет такой вид [2]:

$$
\begin{aligned}
& \overrightarrow{\mathrm{R}} \cdot \sin \delta+\overrightarrow{\mathrm{Q}}_{\mathrm{Bp}}=0 ; \\
& \overrightarrow{\mathrm{R}} \cdot \cos \delta-\overrightarrow{\mathrm{G}}=0 .
\end{aligned}
$$

Система уравнений (1) - (2) записана в скоростной системе координат Ох $а y_{a}$, связанной с несущим винтом. В фрормулах (1) - (2): R - полная аэродинамическая сила НВ на заданном режиме полета; $Q_{\text {вр }}$ с сила вредного сопротивления планера вертолета; G - вес вертолета; $\delta$ - угол между направлением полной аэродинамической силы и нормалью к траектории.

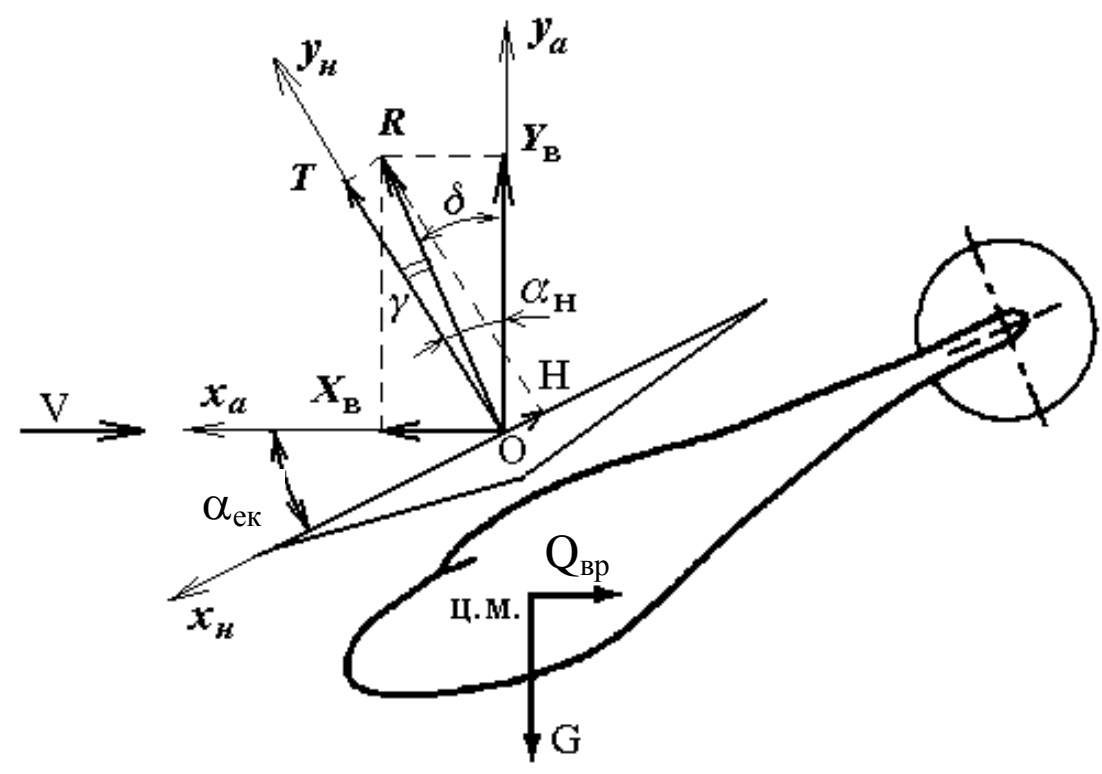

Рис. 1. Схема сил, которые действуют на вертолет в постоянном горизонтальном полете

Конструкция цельнометаллической лопасти НВ вертолета Ми-8 наиболее типовая [3, 4]. Лопасть с прессованным лонжероном и хвостовыми отсеками с сотовыми заполнителями, образующими перо лопасти, имеет прямоугольную фрорму в плане (рис. 2).

Лопасти несущего винта в полете нагружаются аэродинамическими, инерционными силами и силами от собственного веса. Особенности этих нагрузок связаны с характером движения лопасти, которое характеризуется: 
- поступательным перемещением вместе с вертолетом со скоростью $\boldsymbol{V}$;

- вращением относительно вала НВ с угловой скоростью $\omega$;

- маховым движением в вертикальной плоскости (плоскости тяги);

- качанием в плоскости вращения;

- колебаниями относительно оси вращения лопасти (оси осевого шарнира) при изменении циклического и общего шага НВ.

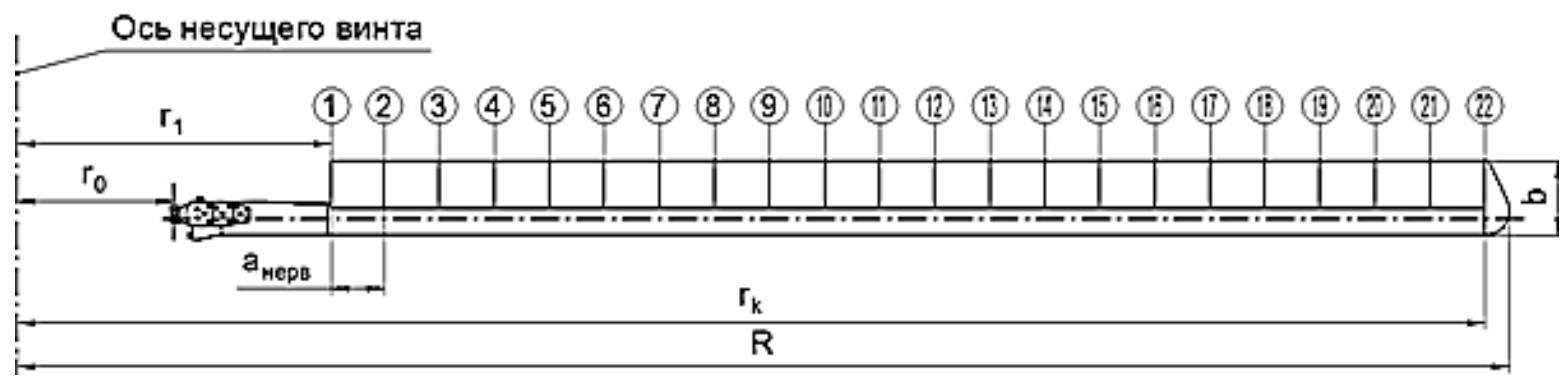

Рис. 2. Общий вид цельнометаллической лопасти НВ в плане:

1-22 - номера сечений лопасти; $r_{0}$ - расстояние от оси НВ до оси наконечника лопасти; $r_{1}$ - расстояние от оси $\mathrm{HB}$ до начала пера лопасти; $\mathrm{R}$ - длина лопасти; $\mathrm{b}$ - ширина (хорда профиля) лопасти; а нерв - расстояние между нервюрами

В результате этого нагрузки изменяются периодически с частотой вращения несущего винта. Поэтому одновременный расчет лопасти на действие всех нагрузок представляет собой достаточно трудоемкую задачу. Дополнительную трудоемкость будут создавать учет упругих изгибных и крутильных деформаций лопасти под действием нагрузок и влияние этих деформаций на величину и характер нагрузок. Для упрощения расчетов целесообразно систему внешних нагрузок разбить на две группы: силы, действующие в плоскости взмаха, силы, действующие в плоскости вращения, и шарнирный момент.

К первой группе относят (рис. 3, а):

- воздушную нагрузку $\boldsymbol{Y}_{\boldsymbol{\theta}}$;

- нагрузку от массы конструкции лопасти $\boldsymbol{G}_{\boldsymbol{л}}$;

- центробежную силу $\boldsymbol{N}_{\mathbf{u \sigma}}$;

- инерционную силу $\boldsymbol{P}_{\boldsymbol{\beta}}$, обусловленную маховым движением лопасти.

При наличии горизонтального шарнира эти силы будут уравновешиваться реакцией $\boldsymbol{R}$ втулки. Реакция $\boldsymbol{R}$ определяется из условия мгновенного равновесия лопасти.

Ко второй группе относят (рис. 3, б):

- лобовое сопротивление $\boldsymbol{X}_{\boldsymbol{\pi}}$;

- инерционную силу $\boldsymbol{P}_{\boldsymbol{\xi}}$, вызванную качанием лопасти;

- центробежную силу $\boldsymbol{N}_{\text {цб }}$;

- инерционную кориолисову силу $\boldsymbol{P}_{\text {kор }}$ от махового движения вращающейся лопасти.

Скорость обтекания элементарного участка лопасти $\boldsymbol{U}_{\boldsymbol{r}}$ при горизонтальном полете составляет 


$$
U_{r}=\omega R+V \cos \alpha \cdot \sin \psi
$$

где $\boldsymbol{\omega} \boldsymbol{R}$ - окружная скорость НВ; $\boldsymbol{V}$ - скорость горизонтального полета вертолета; $\boldsymbol{\alpha}$ - угол атаки НВ; $\boldsymbol{\psi}$ - азимутальное положение лопасти.

Согласно уравнению (3) наблюдается периодическое изменение скоростей обтекания сечений лопасти, что приводит к изменению углов атаки и чисел $\boldsymbol{M}$, а, следовательно, аэродинамических сил и моментов. Под действием перечисленных выше сил и моментов лопасти начинают совершать перемещения в плоскости тяги и в плоскости вращения с переменными по азимуту углами $\boldsymbol{\beta}$ и $\boldsymbol{\xi}$. Это, в свою очередь, вызывает изменение инерционных сил $\boldsymbol{P}_{\beta}$ и $\boldsymbol{P}_{\boldsymbol{\xi}}$ при каждом обороте винта, а также дополнительное периодическое изменение углов атаки и скорости обтекания сечений лопасти.

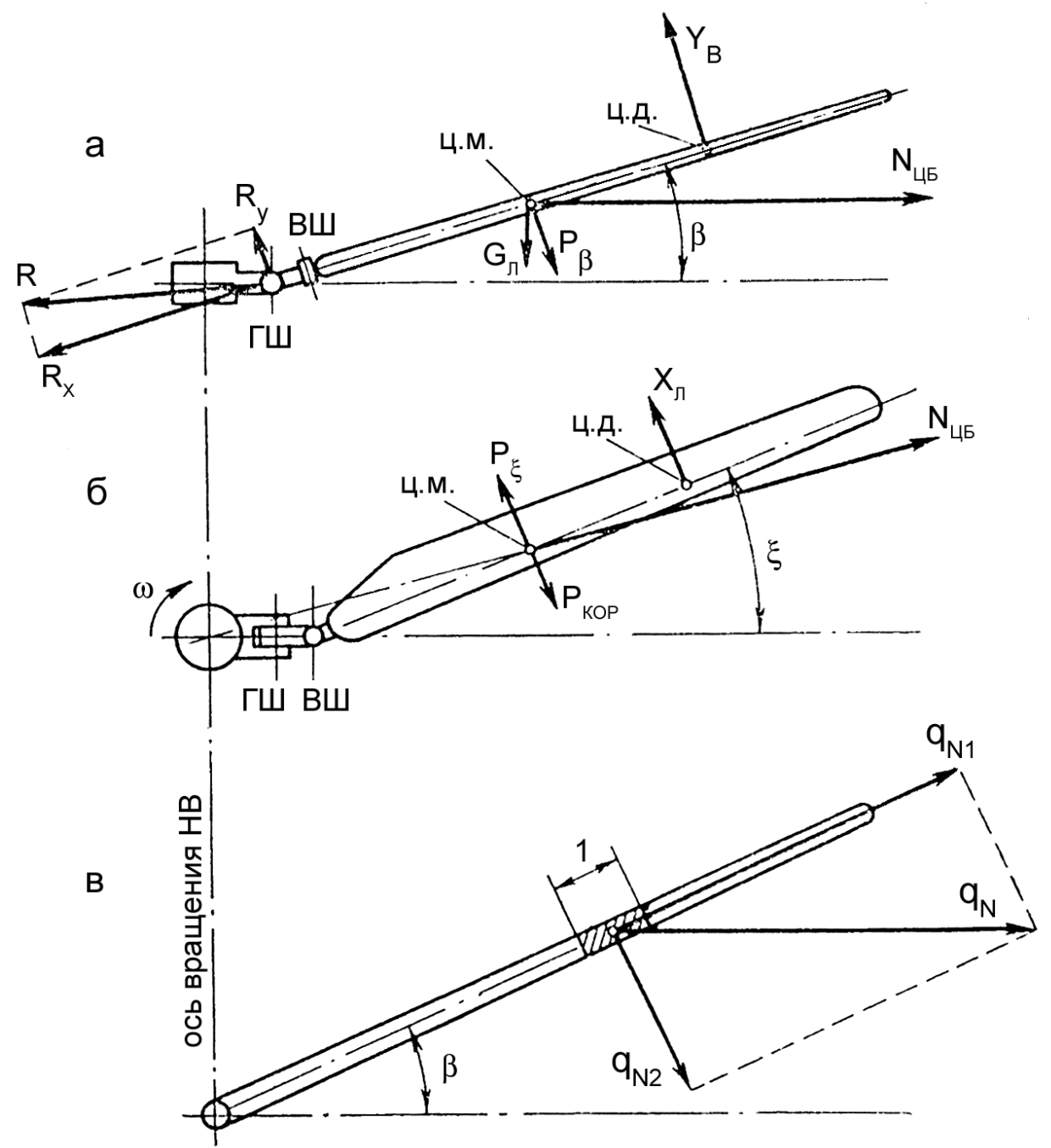

Рис. 3. Силы, действующие на лопасть несущего винта: а - в плоскости взмаха; б - в плоскости вращения винта; в - составляющие погонной центробежной силы; ц.м. - центр масс; ц.д. - центр давления

Различие типов НВ определяется наличием горизонтальных (ГШ) и вертикальных (ВШ) шарниров, а значит, и тем обстоятельством, совершает ли лопасть поворот как жесткое тело или имеют место изгибные деформации ее 
комлевой части. На сегодняшний день можно выделить четыре основных типа несущих винтов:

- шарнирный НВ (рис. 4);

- полужесткий НВ;

- бесшарнирный НВ;

- "жесткий" НВ.

В комлевой части лопасти на алюминиевый прессованный лонжерон 7 установлен стальной наконечник 1, который закреплен на лонжероне болтами 6 и втулками 5 с помощью клеевой пленки МПФ-1 (рис. 5).

Втулки 5 затягивают болтами, которые вворачивают вовнутрь и законтрены проволокой. Во внутренней полости лонжерона на участке сквозных болтов 6 установлена текстолитовая распорка. К торцовой заглушке и полкам лонжерона крепят винтами крышку 9, закрывающую провода штепсельного разъема 10. Провода к противообледенительной системе и лампе контурного огня лопасти расположены в канавке лобовой части лонжерона и подведены к штепсельному разъему в комлевой части лопасти с помощью хомута 8.

В систему сигнализации повреждения металлического лонжерона лопасти НВ входят (рис. 5):

- заглушки, установленные на конце и в комле лопасти и предназначенные для герметизации полости лонжерона;

- сигнализатор давления воздуха 4, включающий в себя сильфонный чувствительный элемент;

- зарядный вентиль 2 с золотником и колпачком 3.

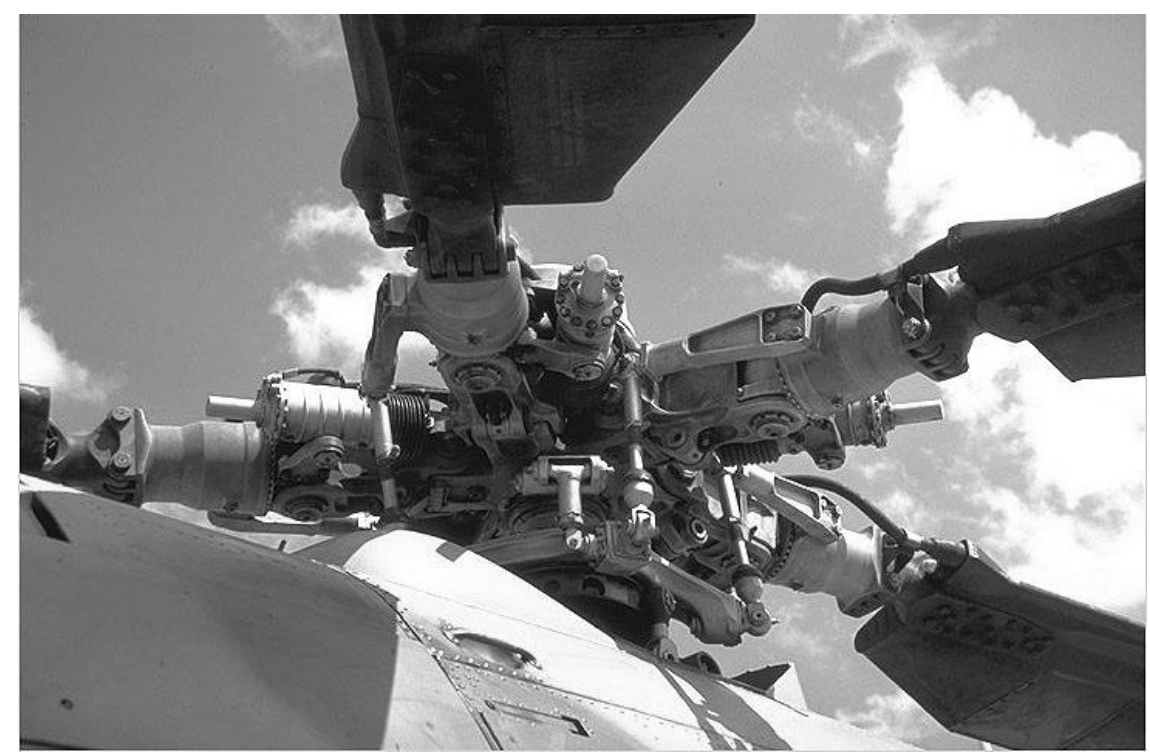

Рис. 4. Шарнирный несущий винт (Ми-24В)

Внутренняя полость металлического лонжерона заполнена воздухом под давлением, превышающим давление начала срабатывания сигнализатора на величину 0,015 $\pm 0,002 \mathrm{MПа.}$

Наконечник металлической лопасти (рис. 6, а) является особо ответственной деталью НВ вертолета. Наконечник металлической лопасти изготовляют механической обработкой из стальной поковки марки 40XH2MA и относят к первой группе контроля по отраслевому стандарту [1]. На рис. 6, б 
показаны заготовки наконечников лопастей НВ после механической обработки поверхностей проушины и вилки (Ми-8 и Ми-2).

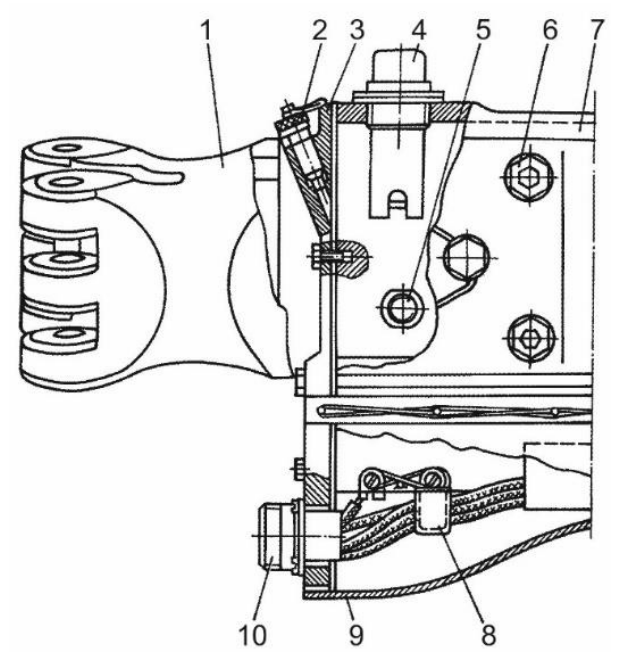

Рис. 5. Схема комлевой части металлической лопасти: 1 - наконечник; 2 - вентиль; 3 - колпачок; 4 - сигнализатор давления в лонжероне; 5 - втулка крепления наконечника; 6 - болты крепления наконечника; 7 - лонжерон;

8 - хомут крепления проводов; 9 - крышка; 10 - штепсельный разъем

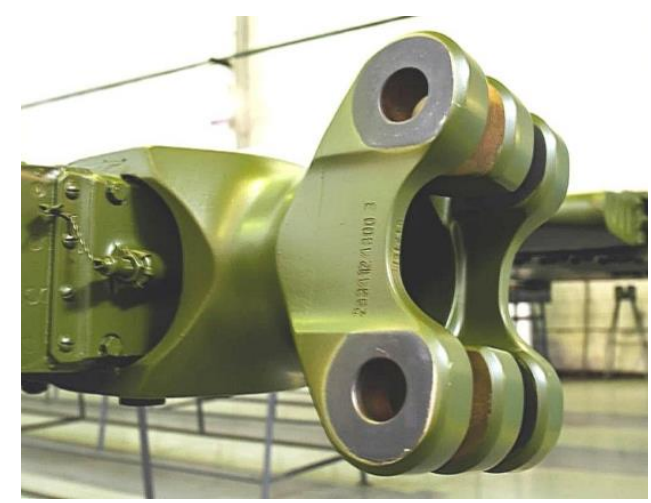

a

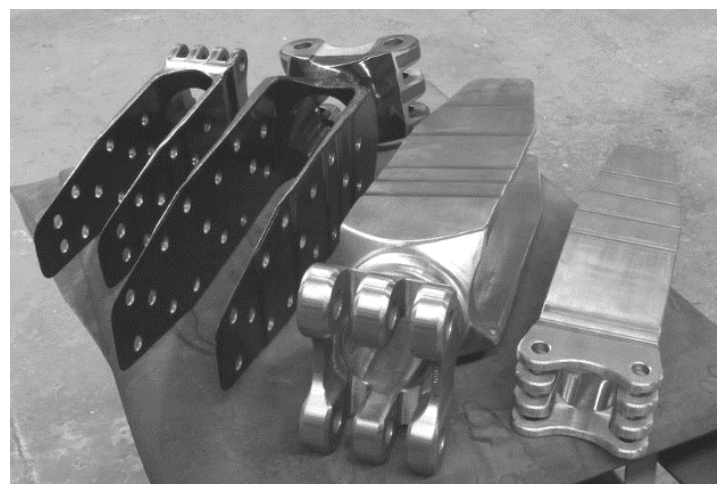

б

Рис. 6. Наконечники металлической лопасти НВ вертолетов

\section{Моделирование металлической лопасти НВ вертолета}

Применение в практике проектирования и конструирования трёхмерных параметрических моделей элементов конструкции (ТПМЭК) даёт возможность проводить численные расчеты аэродинамических и прочностных характеристик как отдельных агрегатов, узлов и деталей, так и всего вертолета в целом с помощью метода конечных элементов [1].

Исходными параметрами для создания ТПМЭК металлической лопасти НВ вертолета являются (рис. 7):

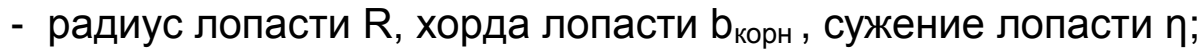

- закон изменения геометрической крутки лопасти;

- тип законцовки и её геометрические параметры;

- тип захвата лопасти и его геометрические параметры;

- тип противообледенительной системы и её геометрические параметры; 
- тип защиты лопасти от аэроабразивного износа и его геометрические параметры;

- тип системы сигнализации повреждения лонжерона и его геометрические параметры;

- количество и геометрические параметры крепёжных элементов;

- расстояние между нервюрами и их геометрические параметры.

ТПМЭК позволяют также определить массовые и инерционные характеристики [1]. ТПМЭК, которые содержат информацию о технологии изготовления (технические требования, значения допусков размеров и форм, а также припусков), позволяют оценить собираемость конструкции и точность сборки.

Предлагаемый метод параметрического моделирования металлической лопасти НВ вертолета с помощью компьютерной системы CATIA V5 является модификацией метода интегрированного проектирования элементов авиационных конструкций, изложенного в [1].

Параметрическая мастер-геометрия лопасти НВ представляет собой линейчатую поверхность, созданную по базовым профилям лопасти.

$\mathrm{Ha}$ базе параметрической мастер-геометрии строят модель распределения пространства, которая определяет положение осевых плоскостей силового набора лопасти для последующего построении моделей деталей лопасти.
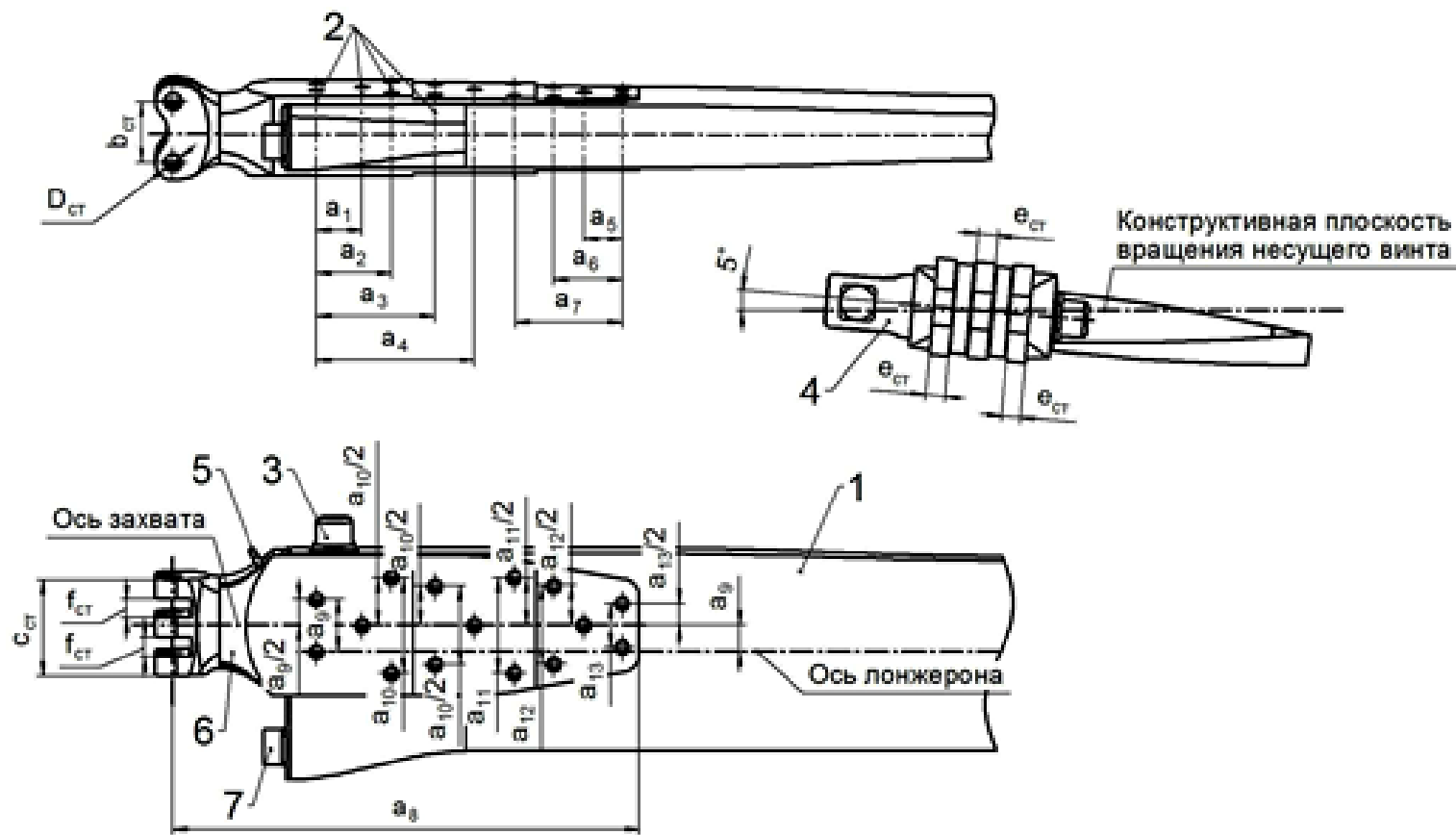

Рис. 7. Параметры лопасти НВ для проектирования и конструирования ТПМЭК: 1 - лонжерон; 2 - оси болтов крепления наконечника к лонжерону, 3 сигнализатор давления воздуха; 4 - крышка-заглушка полости лонжерона; 5 зарядный вентиль; 6 - захват; 7 - штепсельный разъем; $a_{1}, a_{2}, a_{3}, a_{4}, a_{5}, a_{6}, a_{7}$, $a_{8}, a_{9}, a_{10}, a_{11}, a_{12}, a_{13}, b_{c T}, c_{c T}, D_{c T}, e_{c T}, f_{c т}-$ геометрические параметры лопасти

Блок-схема метода параметрического моделирования металлической лопасти НB с помощью системы CATIA V5 включает в себя этапы: 
- Определение геометрических характеристик элементов конструкции лопасти из условия обеспечения статической прочности, усталостной долговечности, живучести, надежности, производственной и эксплуатационной технологичности и их оптимизация по критерию минимальной массы.

- Определение массово-инерционных, аэродинамических характеристик лопасти, характеристик аэроупругости, усталостной долговечности и ресурса, характеристик работоспособности.

- Создание полного электронного определения лопасти в виде аналитических эталонов всех элементов конструкции (рис. 8).

- Разработка конструкторской, технологической, сертификационной и эксплуатационной документации.

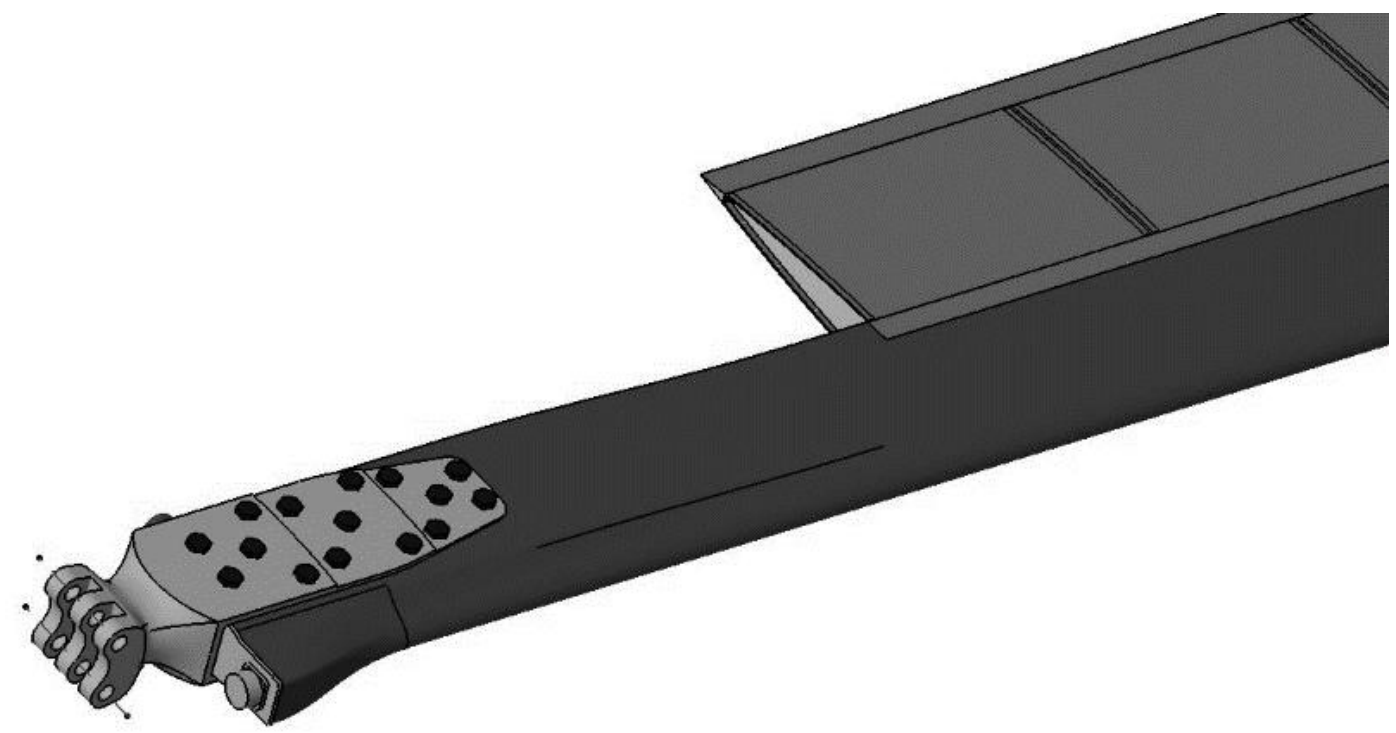

Рис. 8. Фрагмент аналитического эталона конструкции комлевой части металлической лопасти НВ вертолета

В конструкции планера вертолета имеется большое количество концентраторов напряжений и конструктивных нерегулярностей в виде отверстий для установки крепежных элементов [5].

В процессе эксплуатации и ресурсных испытаний конструкций современных вертолетов установлено, что усталостное разрушение силовых элементов конструкции происходит как в зоне концентрации напряжений, так и в зоне интенсивного развития фрреттинг-коррозии [5].

Ресурс планера вертолета должен соответствовать ресурсу регулярной зоны сборных конструкций. Долговечность нерегулярных зон должна превышать долговечность регулярных зон или быть равной ей. Типовыми концентраторами регулярных зон сборных конструкций являются отверстия, заполненные крепежными элементами. Долговечность конструктивных элементов с такими концентраторами определяется характеристиками локального НДС, создаваемого в процессе приложения к элементам переменных нагрузок.

Рассмотрим влияние конструктивно-технологических параметров на характеристики НДС моделей элементов нерегулярных зон сборных конструкций. 


\section{Анализ влияния уровня нагружения на изменение напряженно- деформированного состояния элементов болтового соединения комлевой части лопасти несущего винта вертолета}

Для прогнозирования долговечности и ее изменения при заданном уровне нагрузок необходимо рассчитать локальное напряженнодеформированное состояние, а также добиться уменьшения амплитуды локальных напряжений и деформаций в зоне установки крепежа.

Для анализа НДС в элементах соединения с использованием упругих моделей применяли принцип суперпозиции [5]. При этом получались завышенные значения напряжений, что приводило к погрешности в определении долговечности элементов соединений. При установке болта с радиальным и осевым натягами в конструкции возникают упругопластические деформации.

Применение расчетных комплексов программной реализации метода конечных элементов, одним из которых является ANSYS [0], позволяет учесть и оценить локальное НДС с учетом упругопластического поведения материала.

В качестве объекта исследования выбрана комлевая часть лопасти несущего винта, которая представляет собой многорядное двухсрезное болтовое соединение наконечника с лонжероном (рис. 9). Лонжерон лопасти Dобразной формы с ребрами жесткости каплевидной формы, расположенными на верхней и нижней поверхностях внутреннего контура. Верхние и нижние поверхности наружного контура лонжерона плоские и прилегают по всей поверхности к язычкам наконечника. Наконечник выполнен в виде стыкового узла, образованного тремя проушинами, расположенными сверху и снизу и двух плоских язычков в виде прямоугольных пластин переменной толщины, на поверхности которых расположена группа отверстий $\varnothing 16 \quad$ и 14 мм соответственно (рис. 10).

Геометрическая модель рассчитываемого соединения создана с помощью системы CATIA V5 и на основе формата передачи данных PARASOLID импортирована в систему ANSYS, в которой была построена конечно-элементная модель комлевой части лопасти несущего винта, проведен расчет и анализ полученных результатов.

Расчет проведен при следующих исходных данных: масса лопасти $m_{л}=140$ кг, обороты несущего винта $n=192$ об/мин, длина лопасти $l=10600$ мм.

Построение модели и расчет проведён в декартовой системе координат: ось $X$ направлена вдоль хорды в направлении, противоположном носку профиля лонжерона, ось $Y$ направлена вдоль размаха лопасти в сторону увеличения радиуса, ось Z направлена вниз и при этом образует правую систему координат. 
Відкриті інформаційні та комп'ютерні інтегровані технології, № 90, 2020

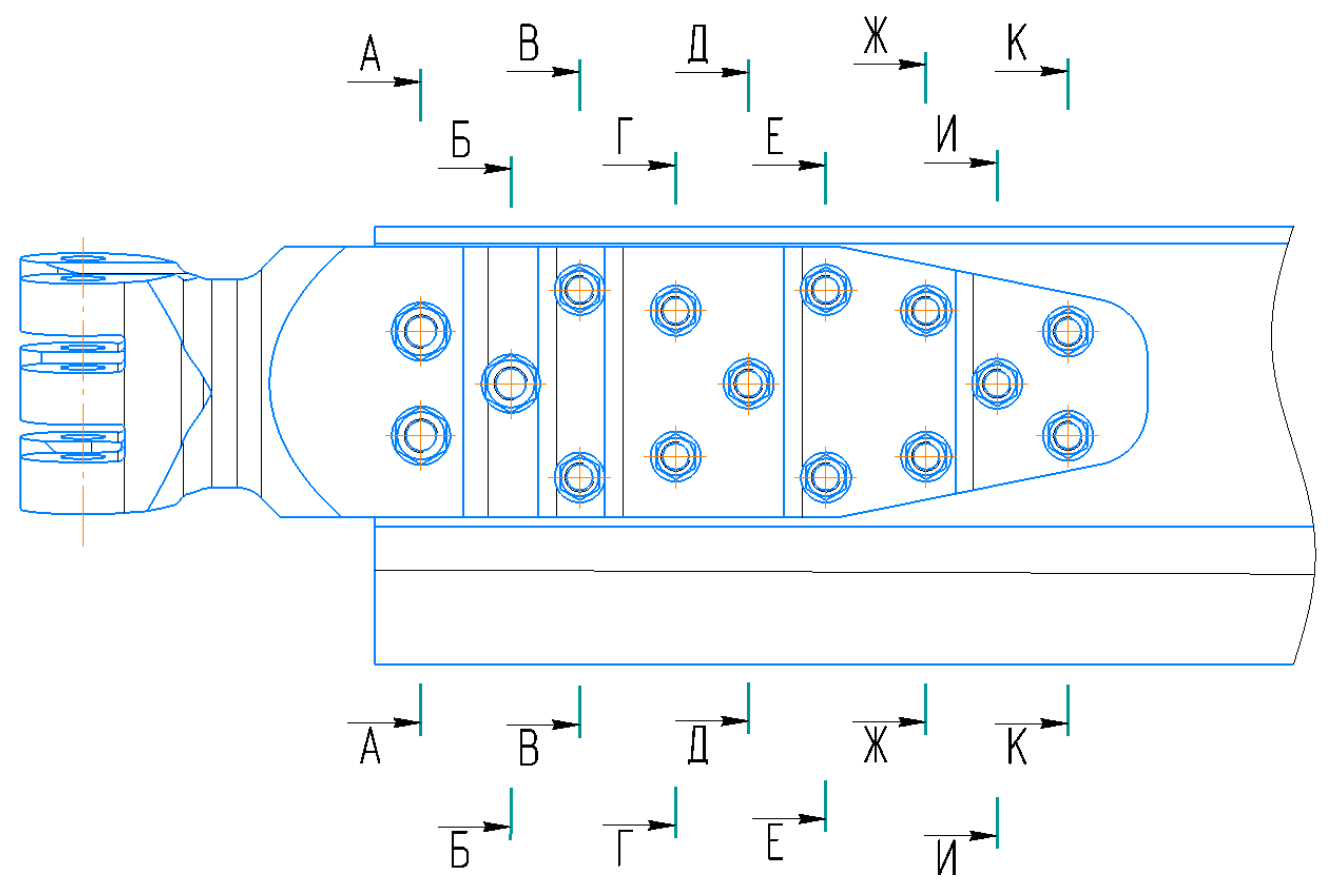

A-A

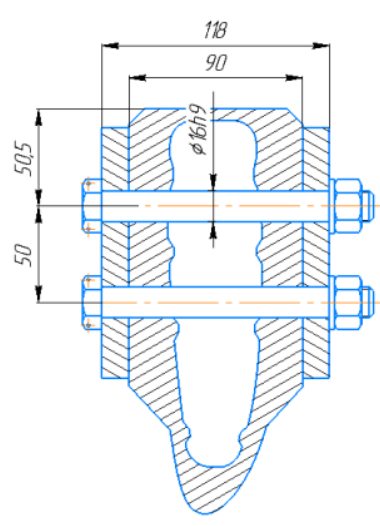

*-*

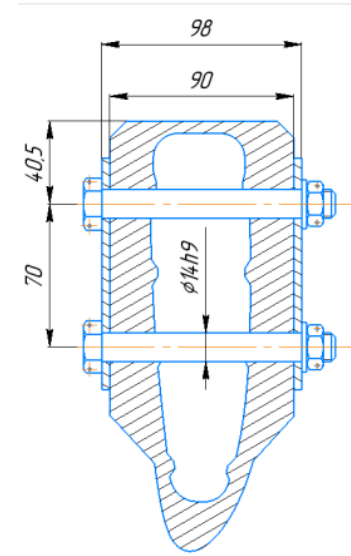

6-5

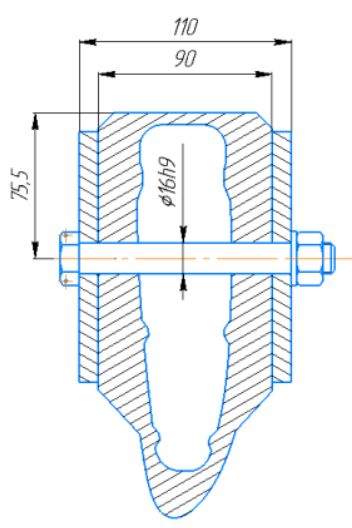

И-И
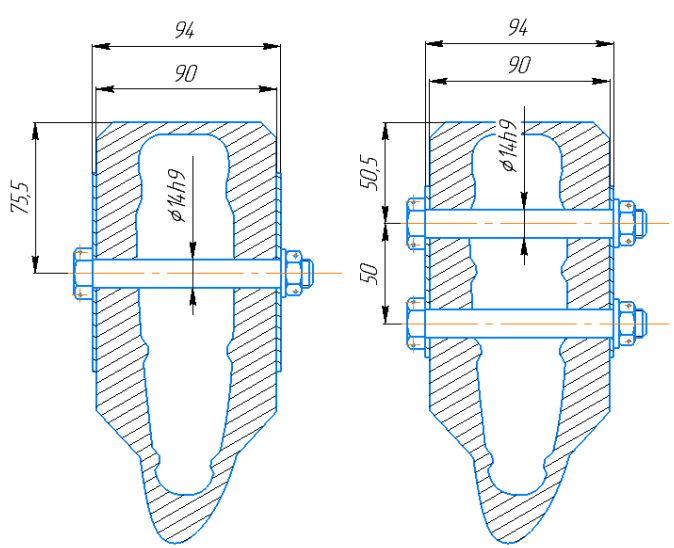

B-B

Рис. 9. Фрагмент болтового соединения комлевой части лопасти несущего винта вертолета 
Відкриті інформаційні та комп'ютерні інтегровані технології, № 90, 2020
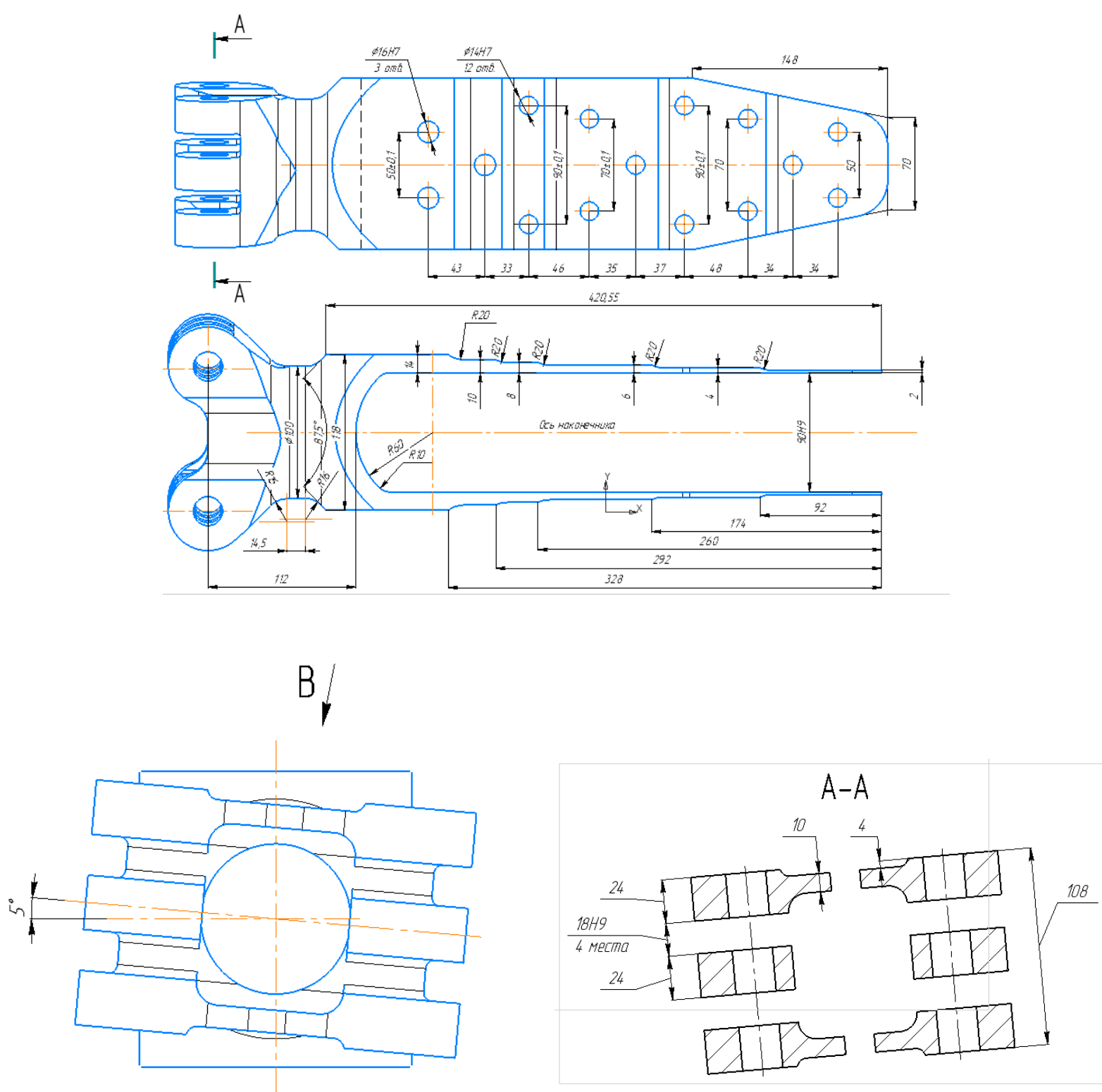

B

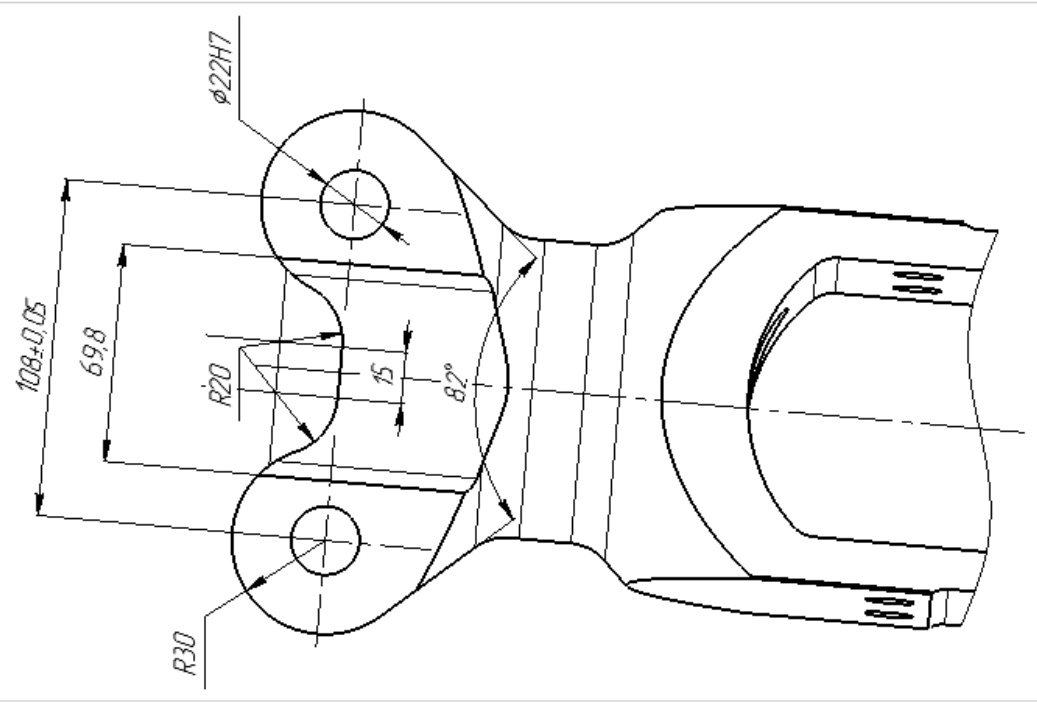

Рис. 10. Наконечник лопасти несущего винта вертолета 


\section{Применяемые материалы и их механические характеристики}

Наконечник лопасти выполнен из стали 40ХН2МА по ГОСТ 4543-71 с механическими характеристиками, приведенными в табл. 1.

Таблица 1

Механические характеристики наконечника лопасти из стали 40XН2MA

\begin{tabular}{|c|c|c|c|c|c|}
\hline $\begin{array}{c}\text { Модуль } \\
\text { упругости Е, } \\
\text { МПа }\end{array}$ & $\begin{array}{c}\text { Коэффиициент } \\
\text { Пуассона, } \\
\text { v }\end{array}$ & $\begin{array}{c}\text { Предел } \\
\text { текучести } \sigma_{\text {т }}, \\
\text { МПа }\end{array}$ & $\begin{array}{c}\text { Предел } \\
\text { прочности } \sigma_{\mathrm{B}} \\
\text { МПа }\end{array}$ & $\begin{array}{c}\text { Удлинение } \\
\text { при разрыве } \\
\delta, \%\end{array}$ & $\begin{array}{c}\text { Предел } \\
\text { выносливости } \\
\sigma_{-1}, \text { МПа }\end{array}$ \\
\hline 210000 & 0,3 & 930 & 1080 & 12 & 519 \\
\hline
\end{tabular}

Лонжерон лопасти несущего винта выполнен из алюминиевого сплава ABT-1, обладающего следующими механическими характеристиками (табл. 2).

Таблица 2

Механические характеристики наконечника лопасти из алюминиевого сплава

\begin{tabular}{|c|c|c|c|c|c|}
\hline $\begin{array}{c}\text { Модуль } \\
\text { упругсти Е, } \\
\text { МПа }\end{array}$ & $\begin{array}{c}\text { Коэффициент } \\
\text { Пуассона } v\end{array}$ & $\begin{array}{c}\text { Предел } \\
\text { текучести } \sigma_{\tau}, \\
\text { МПа }\end{array}$ & $\begin{array}{c}\text { Предел } \\
\text { прочности } \\
\sigma_{\mathrm{B}}, \mathrm{MПа}\end{array}$ & $\begin{array}{c}\text { Удлинение } \\
\text { при разрыве } \\
\delta, \%\end{array}$ & $\begin{array}{c}\text { Предел } \\
\text { выносливости } \\
\sigma_{-1}, \mathrm{MПа}\end{array}$ \\
\hline 70000 & 0,33 & 225 & 294 & 10 & 65 \\
\hline
\end{tabular}

Для описания отклика материалов на внешнее воздействие применяли модель упруго-деформируемого изотропного тела с заданием соответствующих упругих констант материала: модуля упругости первого рода E и коэфффициента Пуассона [7].

\section{Действующие нагрузки и закрепление}

Рассмотрен случай нагружения болтового соединения центробежной силой, возникающей при вращении лопасти. Величину центробежной силы определяли по формуле

$$
N_{\text {ц.б. }}=m_{\text {Л }} r_{\text {ц.т. }} \omega^{2} \text {, }
$$

где $m_{l}$ - масса лопасти, кг; $r_{u . m .}$ - координата центра тяжести лопасти по размаху, мм; $\omega=2 \pi n$ - угловая скорость вращения несущего винта.

С учетом принятых исходных данных получили значение $N_{u . \sigma .}=299960,2 \mathrm{H}$.

Расчетную нагрузку прикладывали в центре тяжести концевого сечения лонжерона и распределяли ее на все узлы торцевого сечения лонжерона, используя связанный контакт с фрормулировкой МРС (фрормулировка контакта с использованием уравнений совместности деформаций) [8].

Рассчитываемую конструкцию закрепляли по стенкам отверстия в проушинах наконечника путем ограничения линейных перемещений по трем направлениям X, Y и Z для всех узлов, расположенных на стенках отверстий.

\section{Конечно-элементная модель болтового соединения и его элементов}

Для разбиения модели болтового соединения на конечные элементы использовали элемент твердого деформируемого тела SOLID185 [9]. Элемент SOLID185 - восьмиузловой элемент, имеющий фрорму гексаэдра и обладающий тремя степенями свободы в каждом из узлов: линейные перемещения вдоль 
осей X, Y и Z соответственно. Помимо базовой фрормы, элемент поддерживает и другие геометрические фрормы, такие, как призма, тетраэдр и пирамида, получаемые в результате вырождения базовой фрормы при разбиении нерегулярных зон со сложной геометрией.

На рис. 11 - 14,а показаны конечно-элементные модели болтового соединения наконечника с лонжероном лопасти несущего винта и его основных конструктивных элементов.

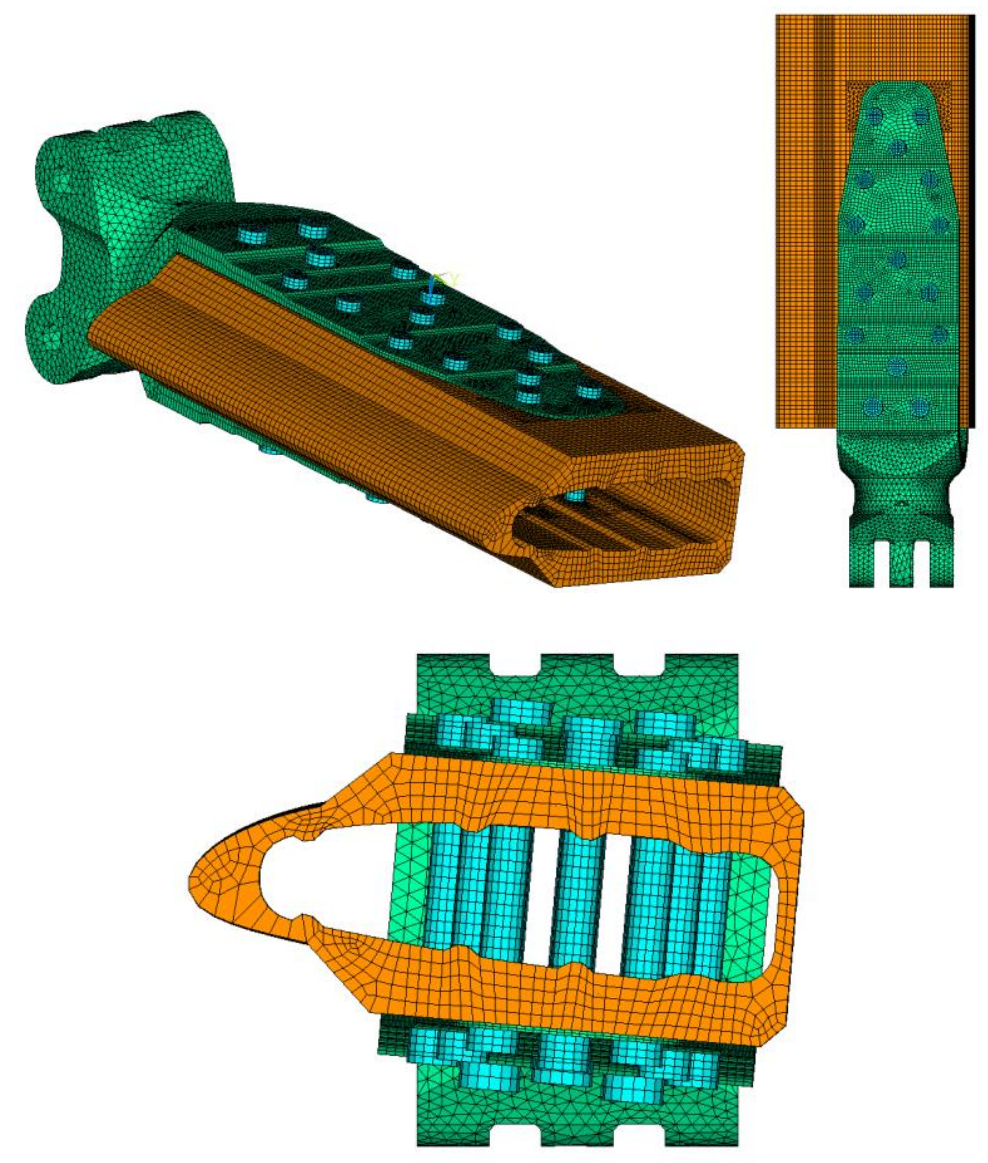

Рис. 11. Конечно-элементная модель болтового соединения наконечника с лонжероном лопасти несущего винта вертолета

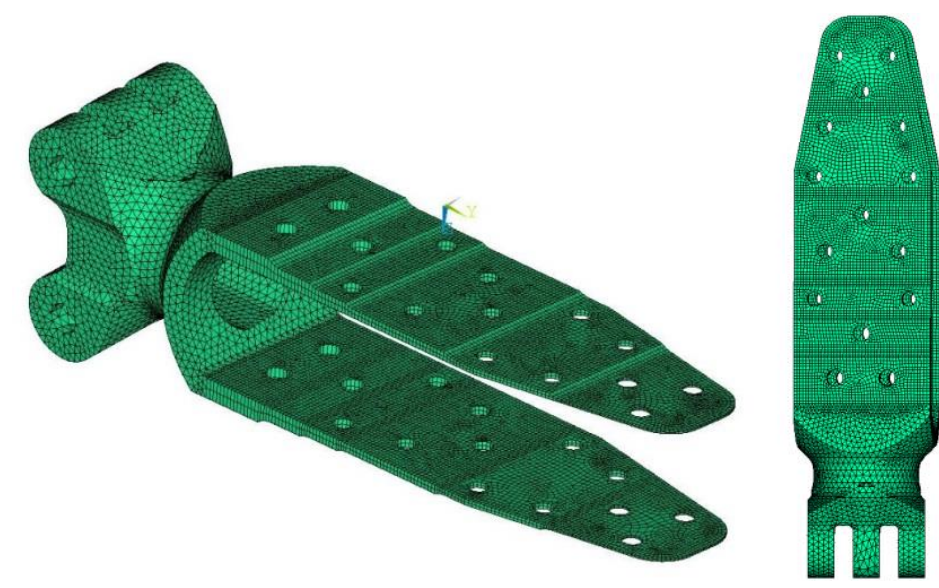

Рис. 12. Конечно-элементная модель наконечника 


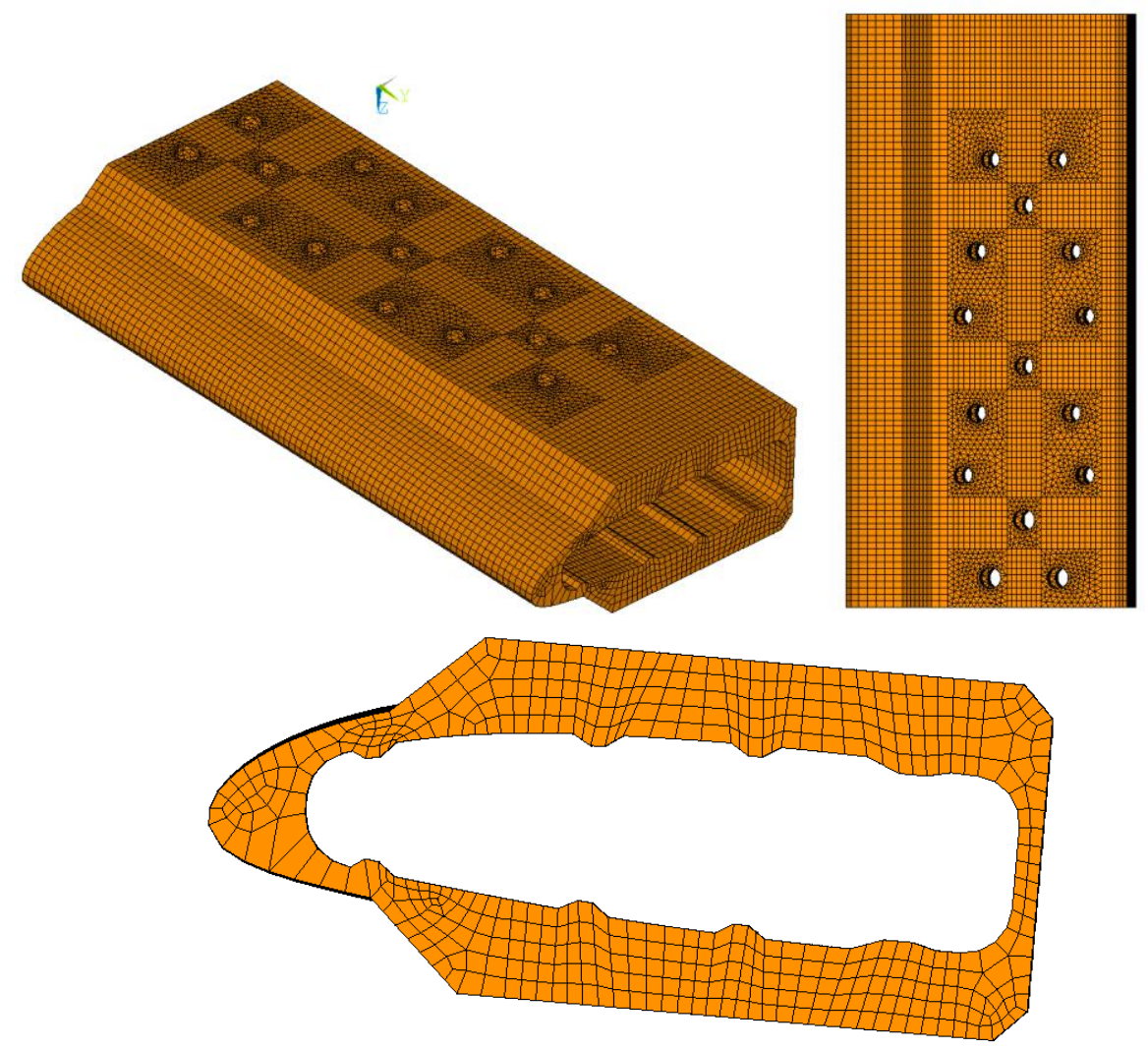

Рис. 13. Конечно-элементная модель лонжерона

Передачу нагрузки между элементами болтового соединения моделировали с помощью контактных элементов TARGE170 и CONTA174 (рис. $14,6)[10]$.

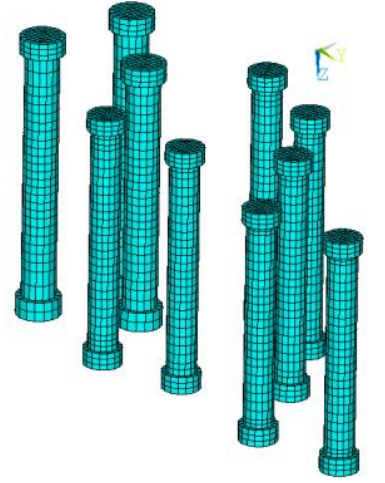

a

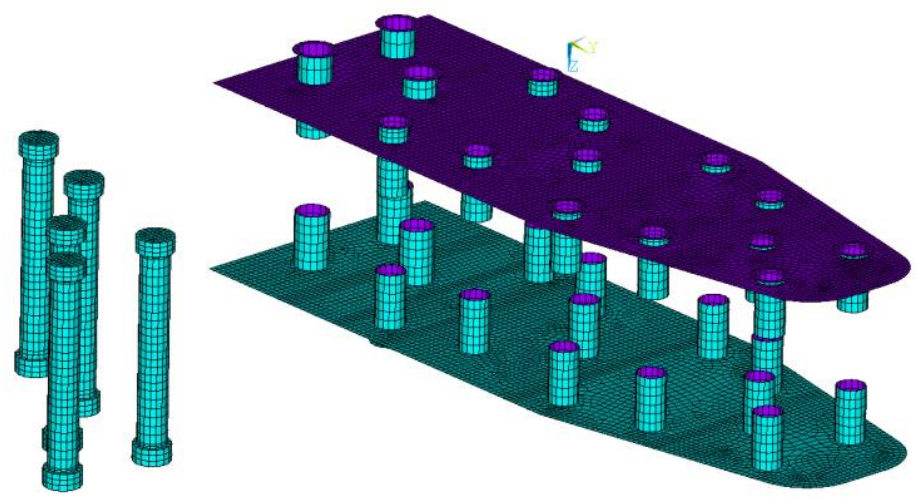

6

Рис. 14. Конечно-элементная модель болтов (а) и контактных элементов (б)

Для моделирования контактного взаимодействия использовали обобщенную модель контактного взаимодействия типа «поверхность в поверхность» [11], в рамках которой рассматривали кулоновскую модель трения, приняв значение коэффрициента статического трения для пары материалов «алюминий по стали» равным 0,15.

В целях снижения общей размерности модели, а следовательно, и вычислительных затрат, выполнили зонирование путем выделения зон с 
разной плотностью разбиения и формой создаваемых конечных элементов. Регулярные объемы с простыми геометрическими фрормами разбивали на элементы, имеющие форму гексаэдра, а нерегулярные зоны со сложной геометрией разбивали элементами в форме тетраэдров.

Таблица 3

Статистические данные о конечно-элементной модели

\begin{tabular}{|l|c|c|c|c|c|}
\hline Показатели & Наконечник & Лонжерон & Болты & $\begin{array}{c}\text { Контактные } \\
\text { элементы }\end{array}$ & $\begin{array}{c}\text { Общая } \\
\text { размерность } \\
\text { модели }\end{array}$ \\
\hline $\begin{array}{l}\text { Количество } \\
\text { элементов }\end{array}$ & 75121 & 137105 & 16784 & 31799 & 261300 \\
\hline $\begin{array}{l}\text { Количество } \\
\text { улов }\end{array}$ & 42129 & 62996 & 22208 & 27052 & 127335 \\
\hline
\end{tabular}

\begin{tabular}{|c|c|c|c|c|}
\hline Форма элемента & Наконечник & Лонжерон & Болты & $\begin{array}{c}\text { Общая } \\
\text { размерность } \\
\text { модели }\end{array}$ \\
\hline Гексаэдр & 18988 & 31370 & 16784 & 261300 \\
\hline Тетраэдр & 56133 & 105735 & - & 127335 \\
\hline
\end{tabular}

При этом принимали средний размер грани элемента для язычков наконечника, разбиваемых гексаэдральными элементами равным 3 мм, а для части модели наконечника, разбиваемой тетраэдральными элементами, средний размер грани равен 6 мм (рис. 15). Средний размер элемента в регулярной зоне лонжерона, разбиваемой гексаэдральными элементами, составил 5 мм, а в нерегулярных зонах на стенках отверстий задавали размер равным 2 мм с переходом к размеру 5 мм на внешних границах объемов (рис. 16).

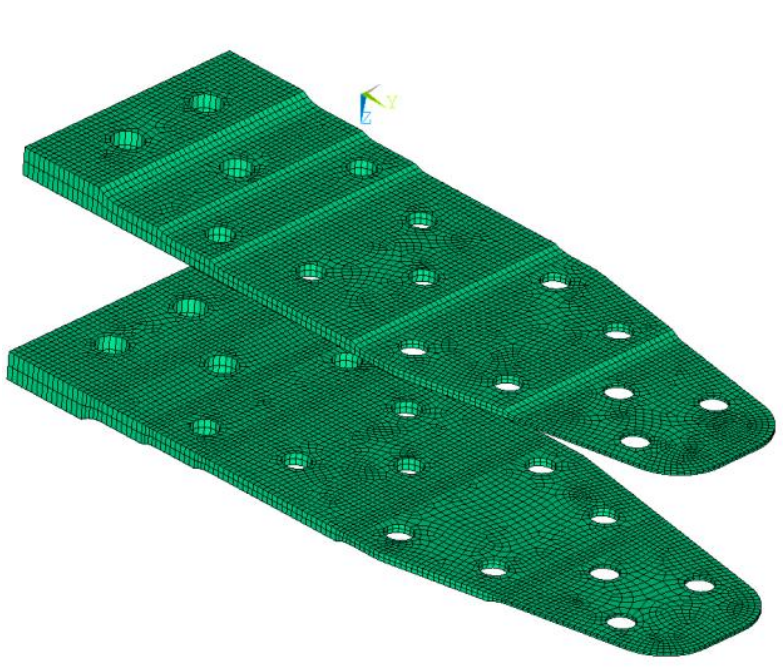

a

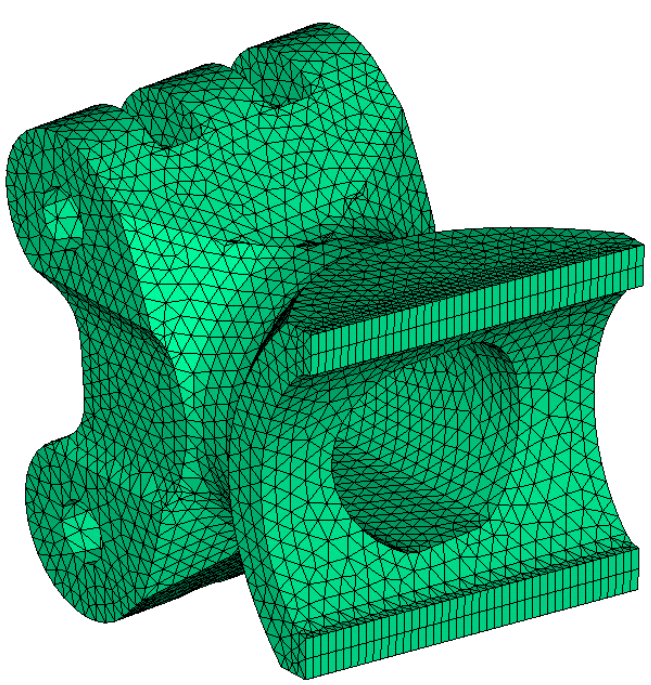

6

Рис. 15. Регулярные и нерегулярные зоны модели наконечника: а - гексаэдральная сетка; б - тетраэдральная сетка 


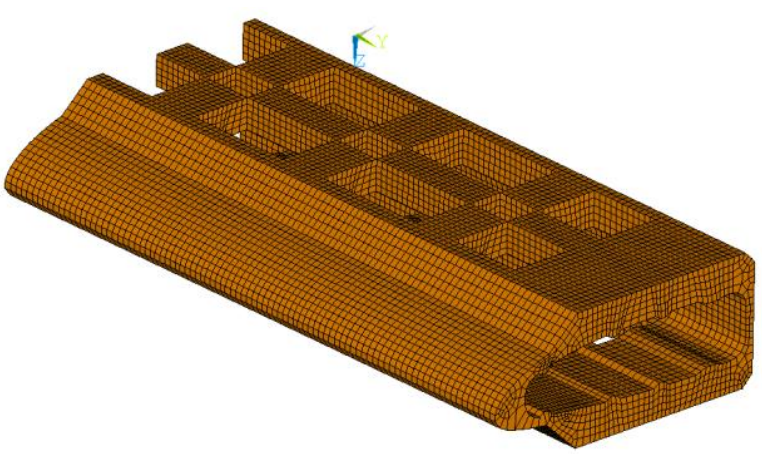

a

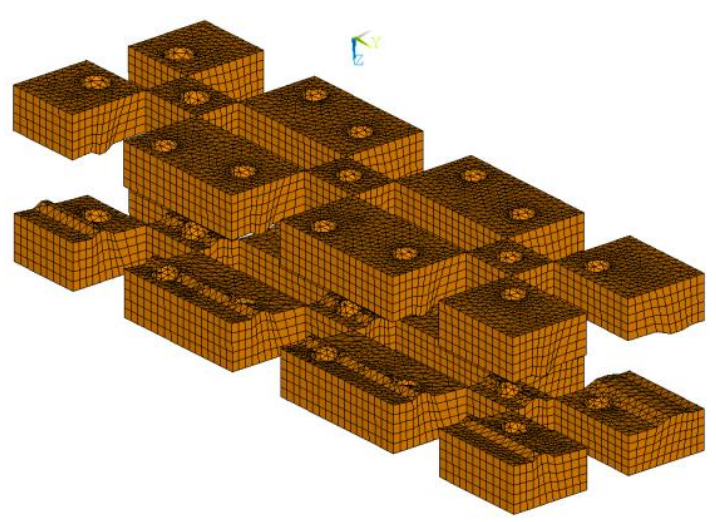

6

Рис. 16. Регулярные и нерегулярные зоны модели лонжерона:

а - гексаэдральная сетка;

б - тетраэдральная сетка

На рис. 17 показана конечно-элементная модель болтового соединения наконечника с лонжероном лопасти несущего винта вертолета с визуализацией приложенной нагрузки и граничных условий.
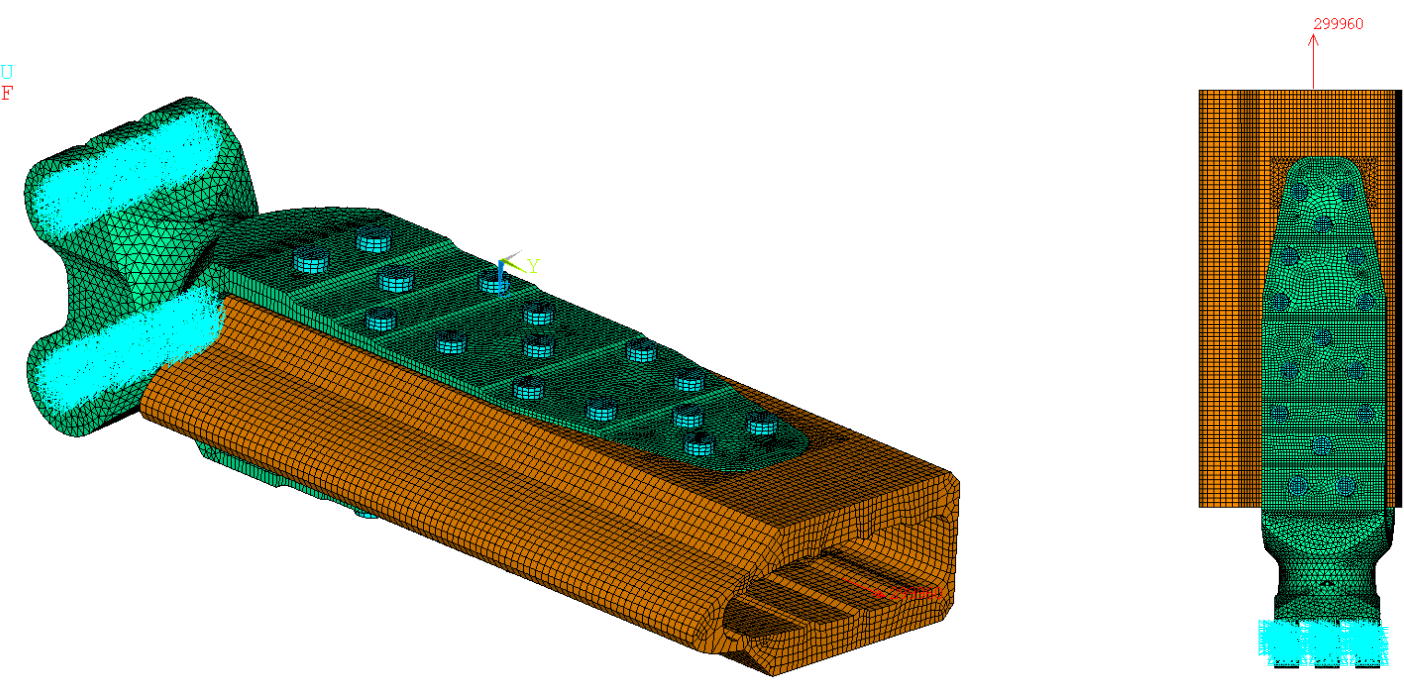

Рис. 17. Визуализация приложенной нагрузки и граничных условий

\section{Анализ результатов расчета}

Анализ результатов расчета включает в себя определение реакций в точках крепления, оценку величин максимальных перемещений элементов конструкции и напряжений в зонах концентрации напряжений.

\section{Реакции в точках крепления наконечника}

В ходе расчета определены реакции в точках крепления наконечника по отверстиям в проушинах.

Суммарные реакции в точках крепления наконечника по отверстиям в проушинах представлены в табл. 4. 
Таблица 4

Суммарные реакции в точках крепления наконечника по отверстиям в проушинах

\begin{tabular}{|c|c|c|}
\hline Fx, H & Fy, H & Fz, H \\
\hline 0,0 & $-299960,0$ & 0,0 \\
\hline
\end{tabular}

Реакции в точках крепления наконечника по верхним отверстиям в проушинах представлены в табл. 5.

Таблица 5

Реакции в точках крепления наконечника по верхним отверстиям в проушинах

\begin{tabular}{|c|c|c|}
\hline Fx, H & Fy, H & Fz, H \\
\hline$-1448,2$ & $-154200,0$ & $-46077,0$ \\
\hline
\end{tabular}

Реакции в точках крепления наконечника по нижним отверстиям в проушинах представлены в табл. 6.

Таблица 6

Реакции в точках крепления наконечника по нижним отверстиям в проушинах

\begin{tabular}{|c|c|c|}
\hline Fx, H & Fy, H & Fz, H \\
\hline$+1448,2$ & $-145760,0$ & $+46077,0$ \\
\hline
\end{tabular}

Анализ реакций в точках крепления наконечника показал, что верхние и нижние проушины нагружены несимметрично. Вследствие внецентренного приложения внешней нагрузки (рис. 18) возникает изгибающий момент относительно оси Z, который воспринимается группой болтов, крепящих лонжерон к язычкам наконечников. Данный момент воспринимается болтами в виде пар сил, действующих в плоскости стыка, которая наклонена к оси X под углом 5०. Из-за наклона плоскости стыка усилия, действующие в плоскости стыка, раскладываются на две составляющие: в направлении $F_{X}$ и $F_{Z}$, о чем свидетельствует результат анализа реакций в верхней и нижней группе проушин.

\section{Перемещения}

Проанализирован характер деформирования болтового соединения в целом и ее отдельных элементов. Проведена оценка суммарных перемещений и компонентов перемещений вдоль осей X и Y. Результаты анализа показаны на рис. 19 - 20. Центробежная нагрузка, приложенная в торцевом сечении лонжерона лопасти, вызывает растяжение лонжерона и язычков наконечника. Наличие эксцентриситета в передаче нагрузки приводит к изгибу и язычков наконечника. 

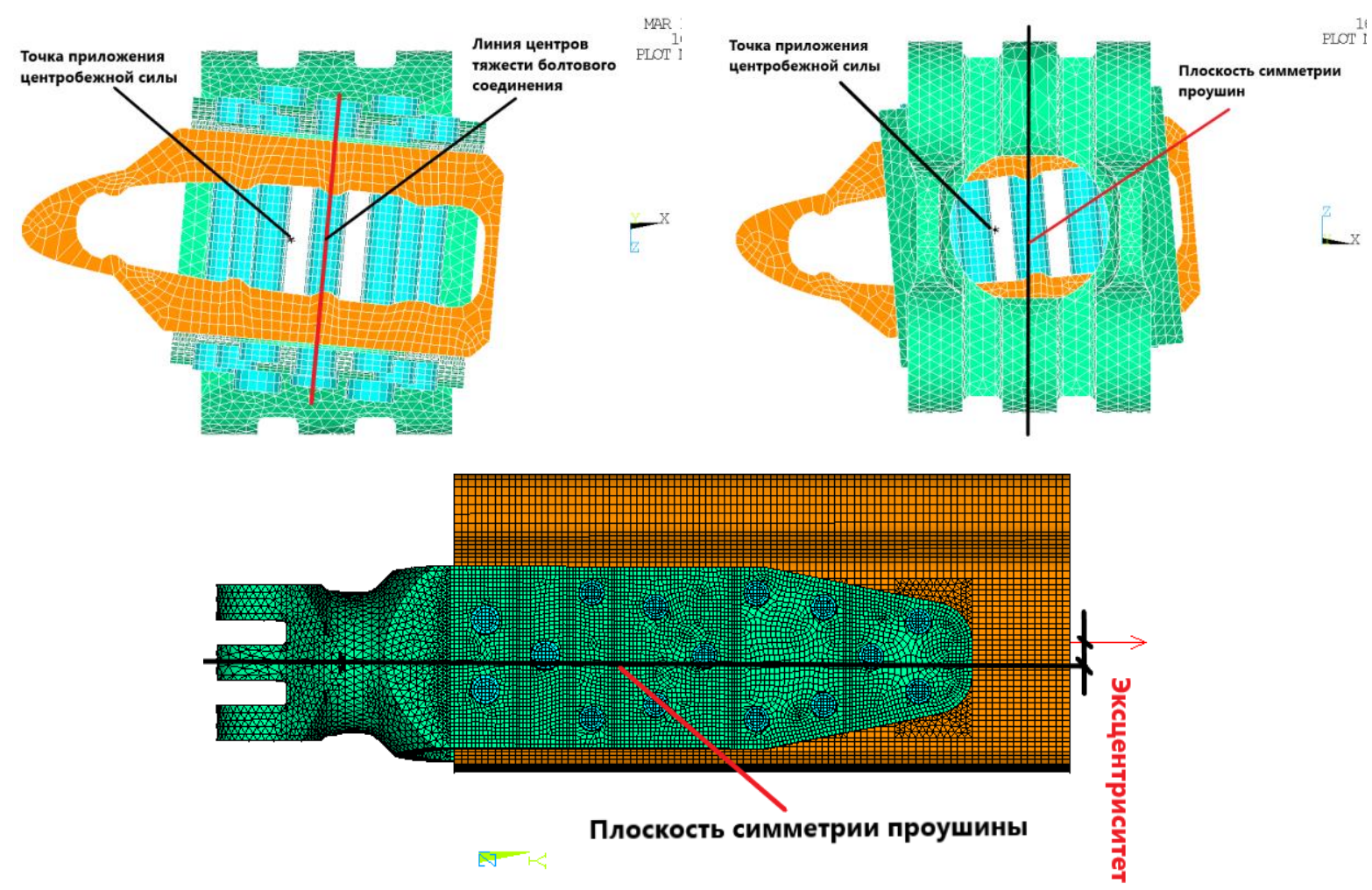

Рис. 18. Положение точки приложения нагрузки относительно линии центров тяжести болтового соединения и плоскости симметрии проушин

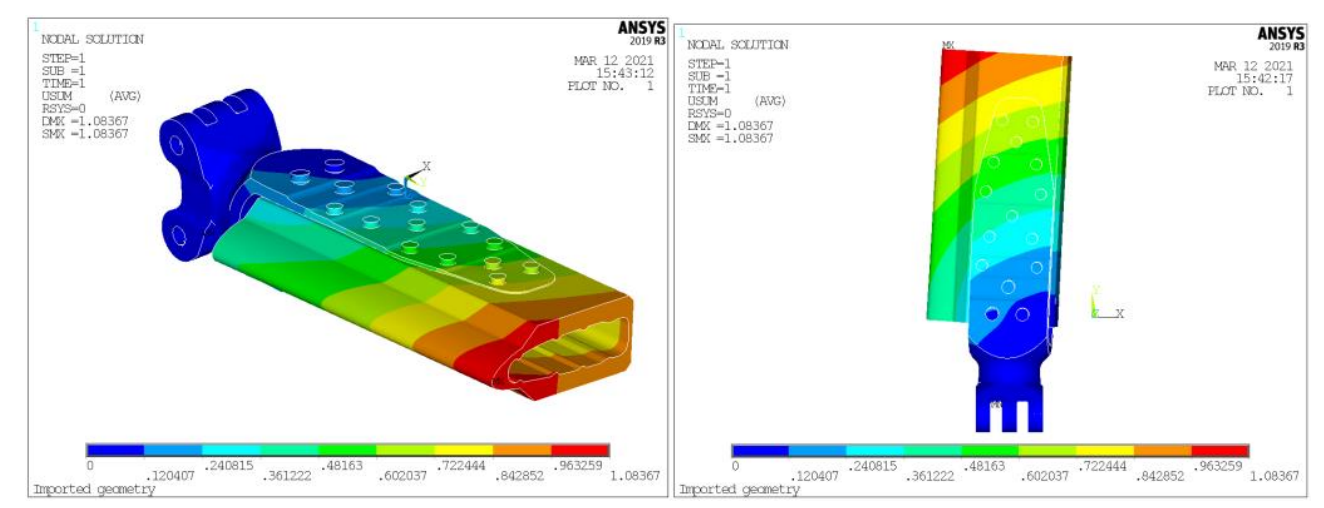

Рис 19. Поле распределения суммарных перемещений в болтовом соединении наконечника с лонжероном лопасти

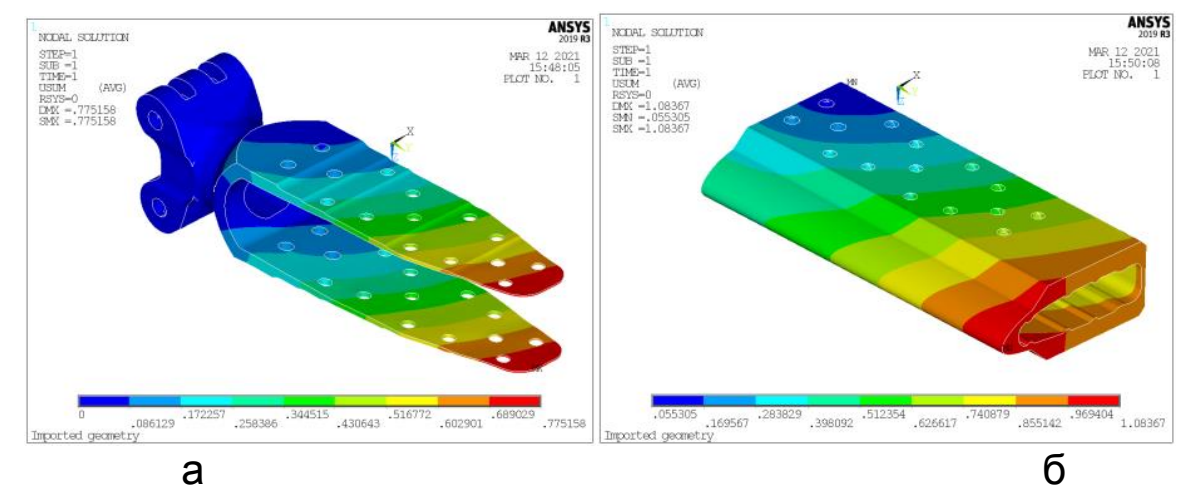

Рис 20. Поле распределения суммарных перемещений:

а - в наконечнике лопасти; б - в лонжероне 
Анализируя полученные результаты, можно сделать следующие выводы.

Картина деформирования несимметрична из-за внецентренного приложения нагрузки. Носок лонжерона деформируется больше, чем его хвостовая часть. Величина максимальных суммарных перемещений конструкции в целом составила 1,08 мм. Величина максимальных суммарных перемещений наконечника составила 0,775 мм.

Вследствие меньшей жесткости язычков наконечника по сравнению с жесткостью проушин происходит их изгиб относительно оси Z. При этом кончики язычков вместе с лонжероном смещаются в направлении, противоположном оси $X$ (рис. 18 - 20). Максимальное смещение язычков в данном направлении составляет 0,72 мм, а лонжерона в торцевом сечении - 0,89 мм соответственно.

Анализ перемещений элементов болтового соединения в направлении оси Y показал, что они деформируются неравномерно, причем участок конструкции ближе к носку лонжерона удлиняется больше, чем тот, что находится в хвостовой части. Величина максимальных удлинений в направлении оси $\mathrm{Y}$ для лонжерона составила 0,62 мм, а для наконечника лопасти - 0,32 мм соответственно.

\section{Напряжения}

Для оценки статической и усталостной прочности элементов болтового соединения наконечника с лонжероном лопасти проанализированы напряжения в силовых элементах по типовым концентраторам. В случае оценки статической прочности анализировали распределение эквивалентных напряжений по Мизесу ( $\left.\sigma_{э к в}\right)$, так как предварительный анализ деформаций показал, что элементы болтового соединения находятся в условиях сложного напряженного состояния (растяжение с изгибом). Максимальные значения напряжений по Мизесу для типовых зон концентрации напряжений сравнивали с пределом прочности материала, из которого изготовлен рассчитываемый элемент конструкции. Для оценки усталостной прочности анализировали распределение главных растягивающих напряжений $\left(\sigma_{1}\right)$ в силовых элементах по типовым концентраторам напряжений. Максимальные значения этих напряжений сравнивали с пределом выносливости материала конструктивного элемента.

\section{Оценка статической прочности элементов болтового соединения наконечника с лонжероном лопасти несущего винта}

В ходе расчета определены эквивалентные напряжения по Мизесу в силовых элементах болтового соединения наконечника лопасти с лонжероном. Результат представлен в виде полей распределения напряжений в зонах концентрации напряжений. Результат расчета показал, что напряжения на нижней поверхности профиля лонжерона и наконечника лопасти выше, чем на верхней. Поэтому в целях сокращения объемов расчета результат представлен только для нижней поверхности. Проанализировано распределение напряжений в зоне отверстий по рядам, начиная от корневого сечения в сторону увеличения координаты $\mathrm{Y}$. 


\section{Лонжерон}

Анализ распределения эквивалентных напряжений по Мизесу в лонжероне показал, что наиболее нагруженным участком конструкции является зона крайнего отверстия $\varnothing 14$ мм, расположенного на нижней наружной поверхности профиля лонжерона ближе к носку (рис. 21 а). Максимальные напряжения локализованы вблизи кромки отверстия по дуге контакта с болтом со стороны меньшей перемычки отверстия. Вследствие концентрации напряжений вблизи контура отверстия наблюдается ярко выраженная неравномерность распределения напряжений. Величина максимальных эквивалентных напряжений по Мизесу в этой зоне составляет 241,4 МПа (рис. $21, б)$. По мере удаления от края отверстия напряжения резко падают до уровня напряжений в регулярной зоне. Отверстия расположены достаточно далеко друг от друга, и поэтому не наблюдается взаимное влияние отверстий.

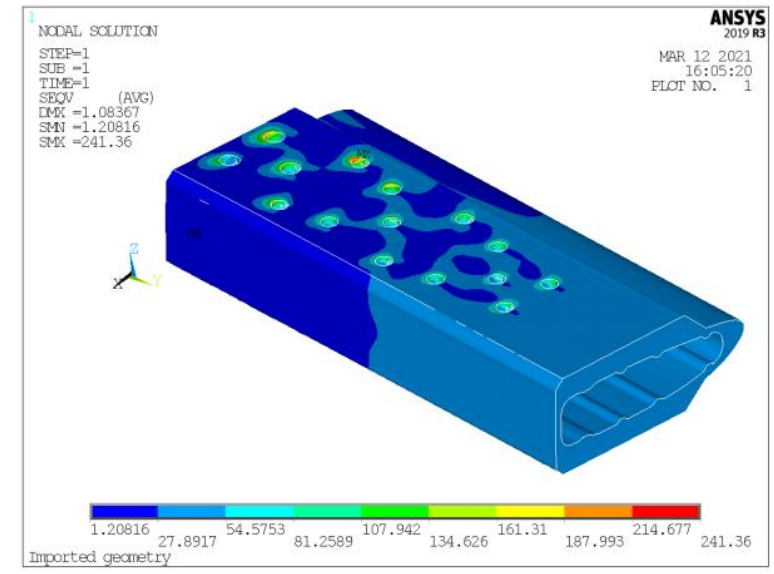

a

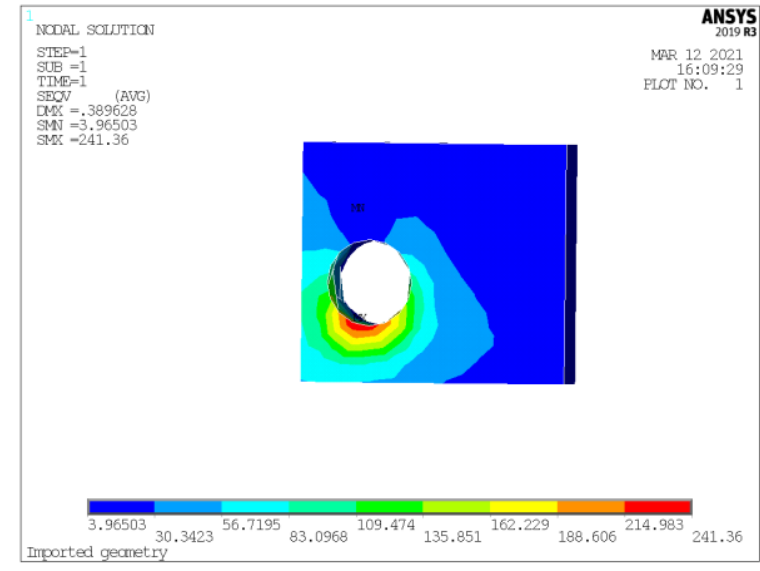

6

Рис 21. Поле распределения эквивалентных напряжений по Мизесу:

а - в лонжероне; б - в зоне первого ряда отверстий $\varnothing 14$ мм

(зона максимальных напряжений;

вид на нижнюю поверхность профиля снаружи)

На рис. 22 - 23 показан характер распределения эквивалентных напряжений по Мизесу в лонжероне в зоне расположения рядов крепежных отверстий.

Величина максимальных напряжений в зоне расположения группы отверстий $\varnothing 16$ мм ниже, чем в зоне крайнего ряда отверстий $\varnothing 14$ мм, и составляет 197,0 МПа.

По мере перехода от одного ряда к другому и приближения к торцевому сечению лонжерона уровень максимальных напряжений снижается.

Следует отметить, что величина эквивалентных напряжений по Мизесу в лонжероне по всем рассмотренным концентраторам не превышает предел прочности материала $\sigma_{\mathrm{B}}=294 \mathrm{MПа}$. 


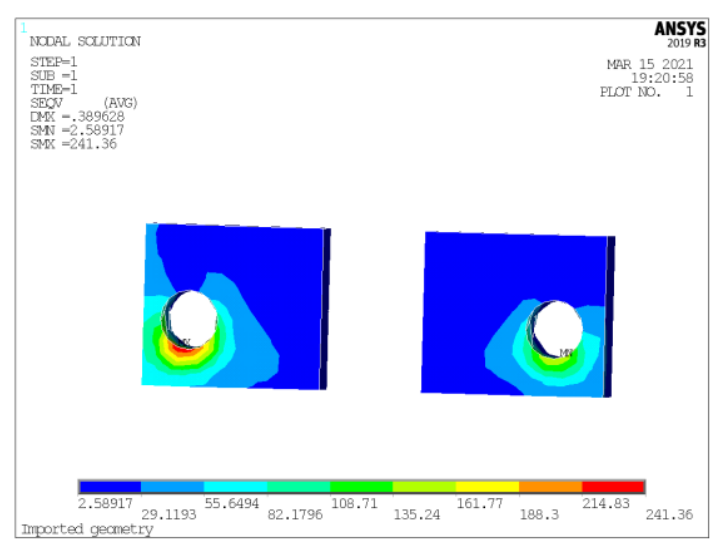

a

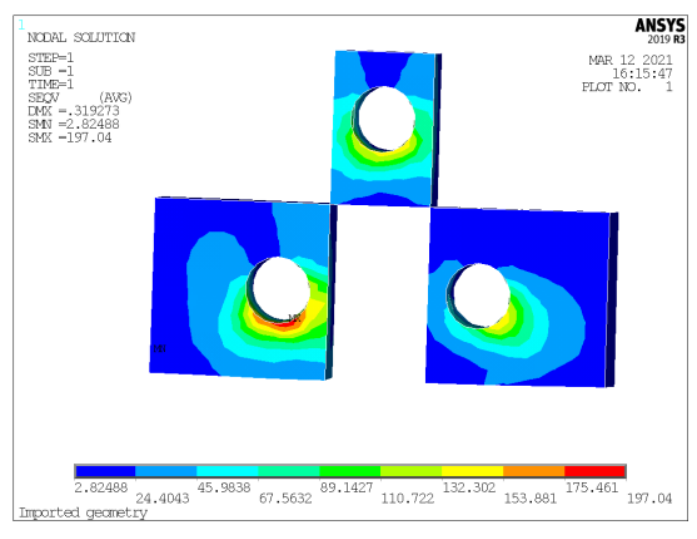

6

Рис 22. Поле распределения эквивалентных напряжений по Мизесу в лонжероне: а - в зоне первого ряда отверстий $\varnothing 14$ мм; б - в зоне расположения группы отверстий $\varnothing 16$ мм

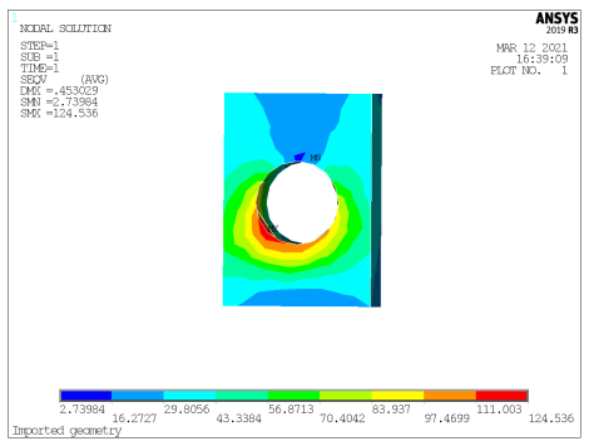

a

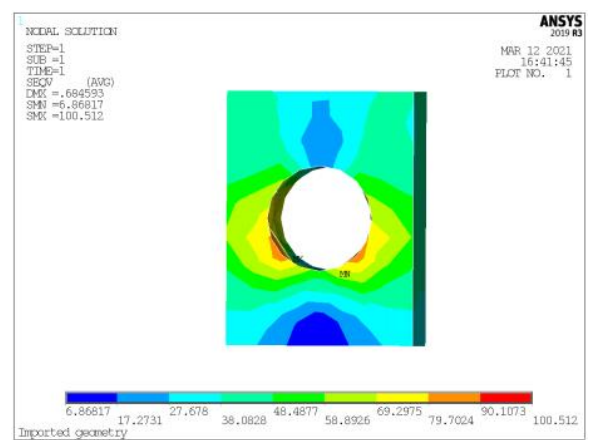

6

Рис 23. Поле распределения эквивалентных напряжений по Мизесу в лонжероне: а - в зоне первого центрального отверстия $\varnothing 14$ мм; $б$ - в зоне второго центрального отверстия $\varnothing 14$ мм

\section{Наконечник}

На рис. 24 - 27 показан характер распределения эквивалентных напряжений по Мизесу в наконечнике в зоне расположения крепежных отверстий и проушин.

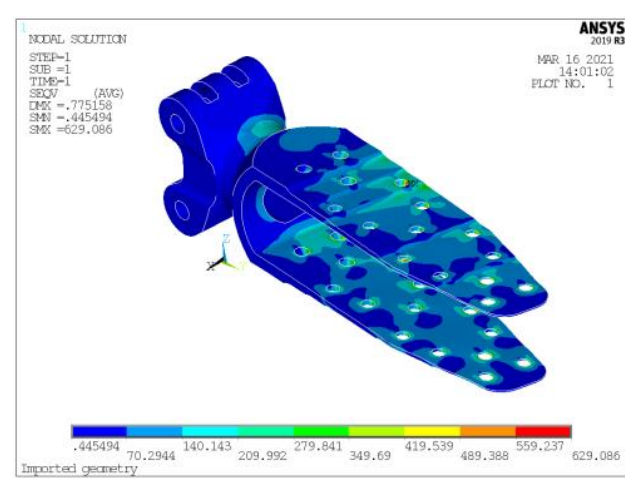

a

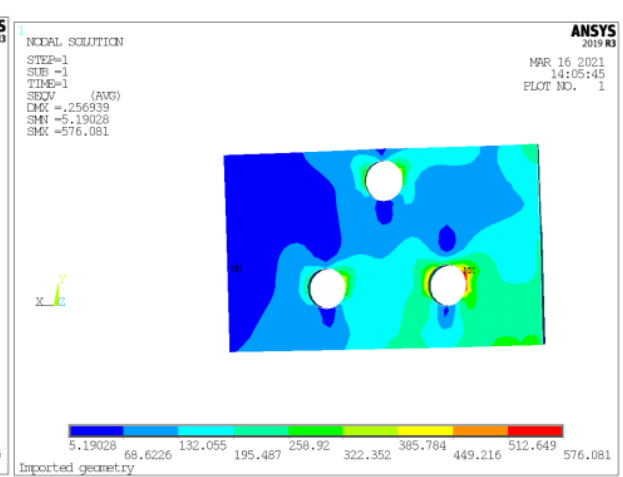

6

Рис 24. Поле распределения эквивалентных напряжений по Мизесу:

a - в наконечнике лопасти; б - в зоне расположения группы отверстий $\varnothing 16$ мм (вид на нижний язычок наконечника изнутри) 


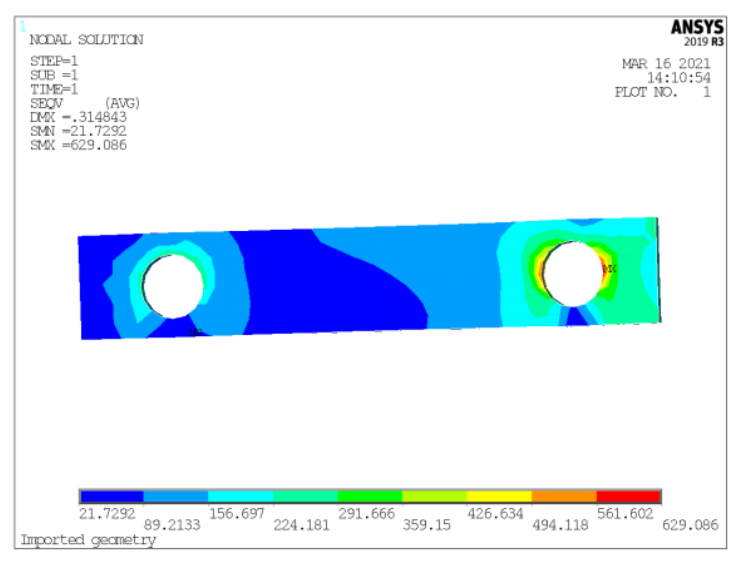

a

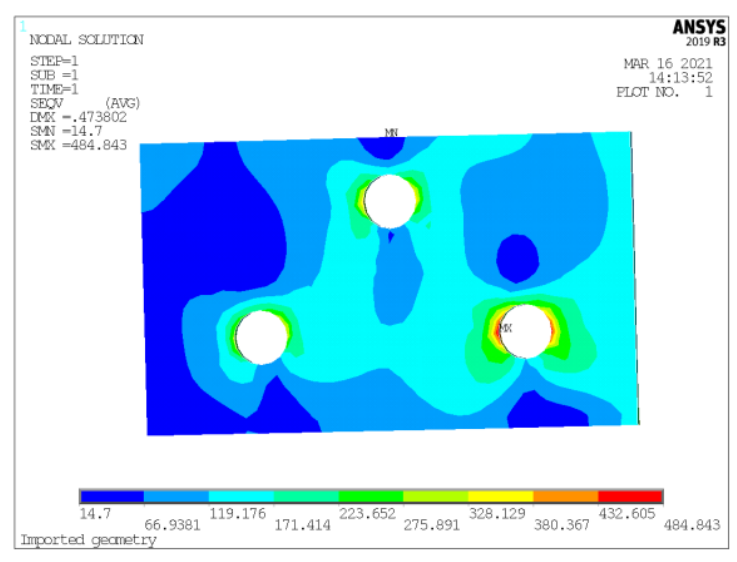

б

Рис 25. Поле распределения эквивалентных напряжений по Мизесу в наконечнике лопасти: а - в зоне первого ряда отверстий $\varnothing 14$ мм;

б - в зоне второго ряда отверстий $\varnothing 14$ мм

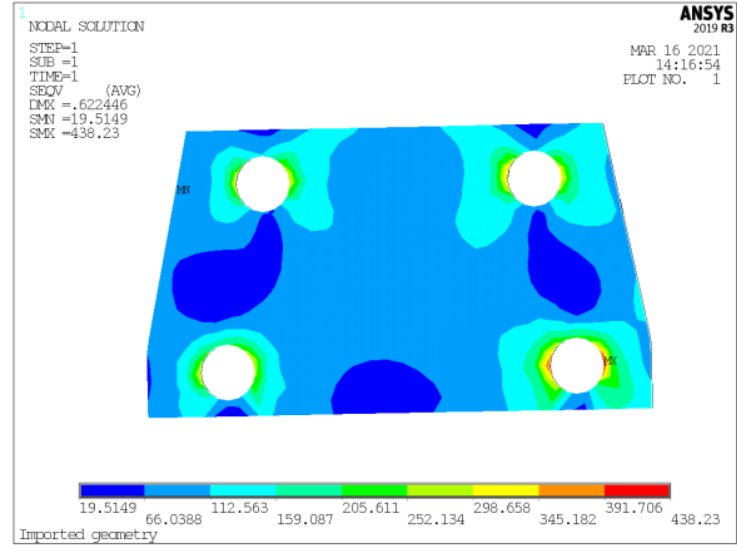

a

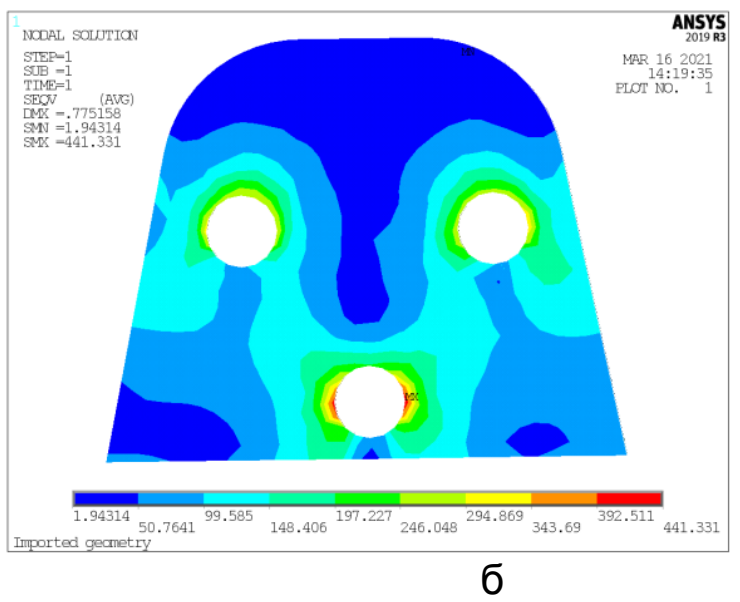

Рис 26. Поле распределения эквивалентных напряжений по Мизесу в наконечнике лопасти: а - в зоне третьего и четвертого рядов отверстий $\varnothing 14$ мм; б - в зоне пятого ряда отверстий $\varnothing 14$ мм

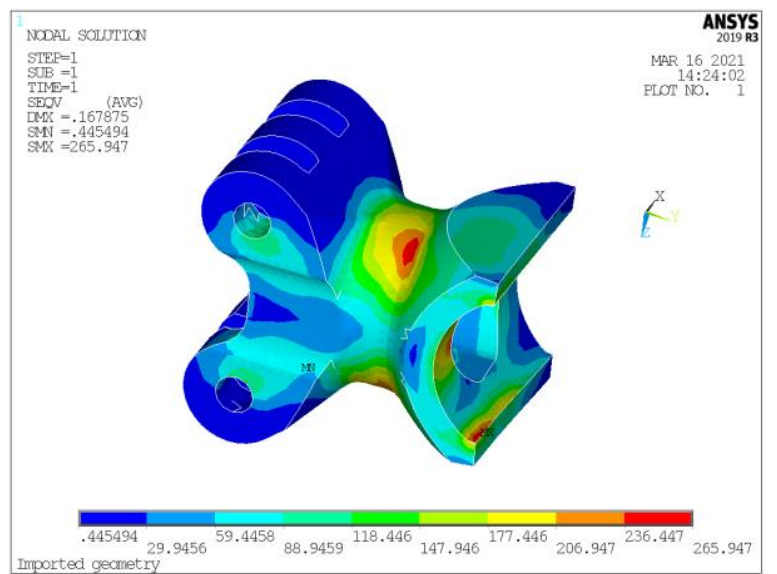

a

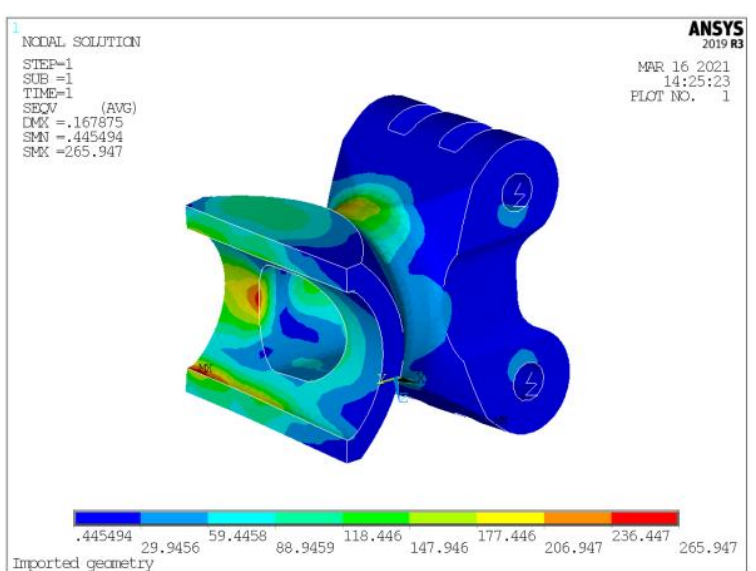

6

Рис 27. Поле распределения эквивалентных напряжений по Мизесу в наконечнике лопасти в зоне вилки 
Анализ распределения эквивалентных напряжений в наконечнике показал, что зона максимальных напряжений локализована вблизи крайнего ряда отверстий $\varnothing 14$ мм. Максимальные значения напряжений в данной зоне достигают значения $\sigma_{\text {эв }}=629,1 \mathrm{MПа}$. По мере перехода от одного ряда к другому уровень максимальных напряжений снижается. Уровень действующих напряжений вблизи отверстий не превышает предел прочности материала наконечника $\sigma_{\mathrm{B}}=1080 \mathrm{MПа}$. Величина максимальных напряжений по Мизесу в зоне проушин составляет $\sigma_{\text {экв }}=265,95 \mathrm{MПа}$, что существенно ниже, чем в зоне отверстий.

\section{Оценка усталостной прочности элементов болтового соединения наконечника с лонжероном лопасти несущего винта}

Для оценки усталостной прочности элементов болтового соединения комлевой части лопасти несущего винта анализировали характер распределения главных растягивающих напряжений в местах концентрации напряжений (рис. 28-30), поскольку именно растягивающие напряжения оказывают влияние на усталостную прочность конструкции. Как правило, усталостные трещины зарождаются в зоне концентрации напряжений и развиваются перпендикулярно действию главных растягивающих напряжений.

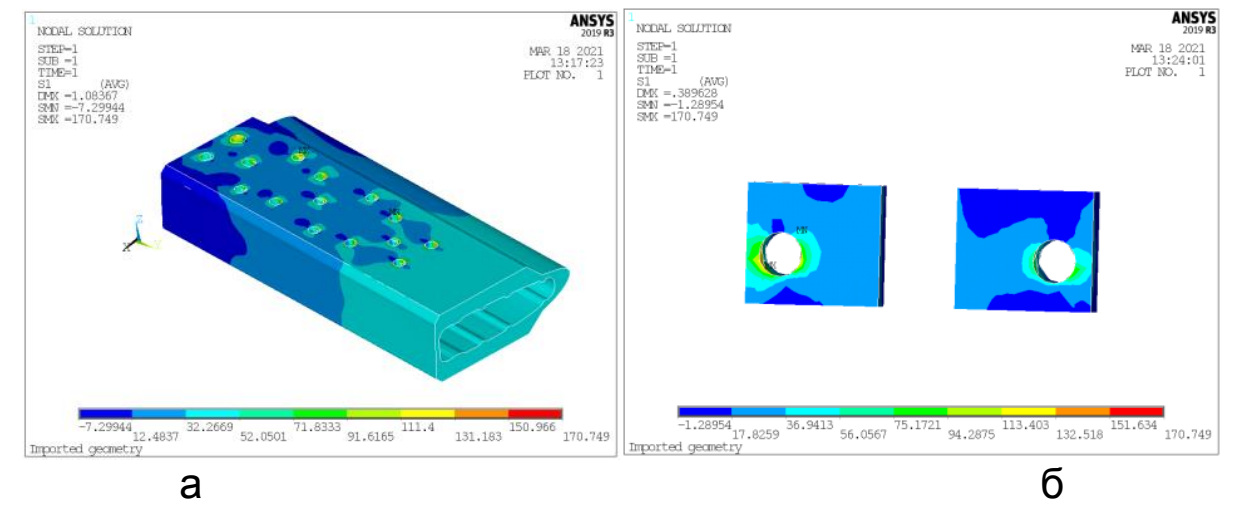

Рис 28. Поле распределения главных растягивающих напряжений: а - в лонжероне; б - в зоне первого ряда отверстий $\varnothing 14$ мм (зона максимальных напряжений вид на нижнюю поверхность профиля снаружи)

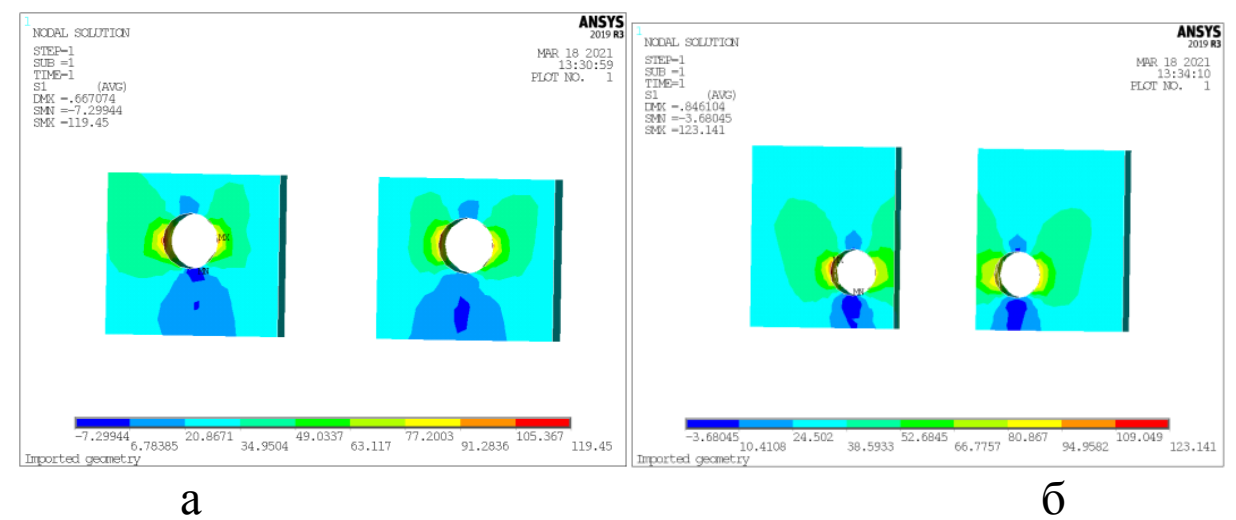

Рис 29. Поле распределения главных растягивающих напряжений в лонжероне:

а - в зоне четвертого ряда отверстий $\varnothing 14$ мм;

б - в зоне пятого ряда отверстий $\varnothing 14$ мм 


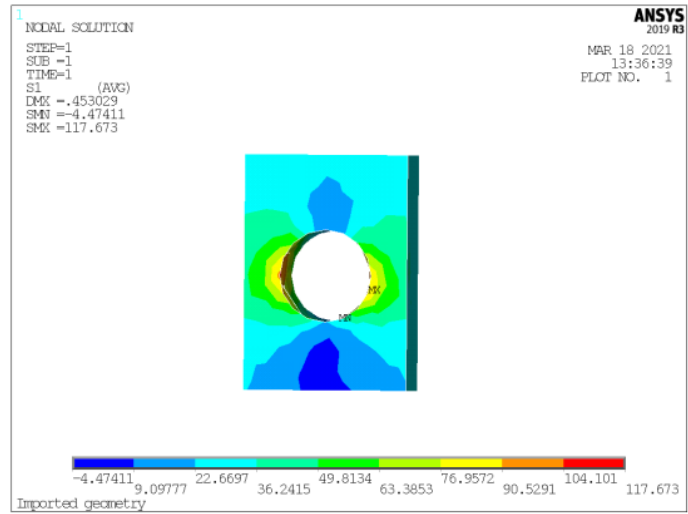

a

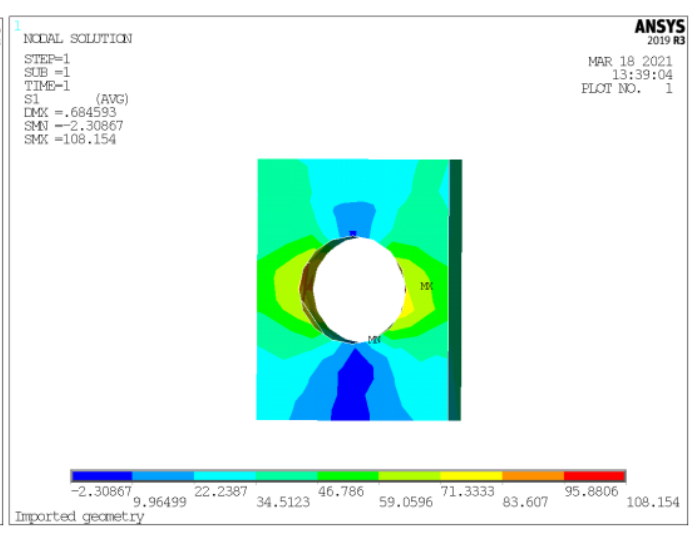

6

Рис 30. Поле распределения главных растягивающих напряжений в лонжероне: а - в зоне первого центрального отверстия $\varnothing 14$ мм;

б - в зоне второго центрального отверстия $\varnothing 14$ мм

\section{Наконечник}

На рис. 31 - 34 показан характер распределения главных растягивающих напряжений в наконечнике лопасти для типовых концентраторов напряжений.

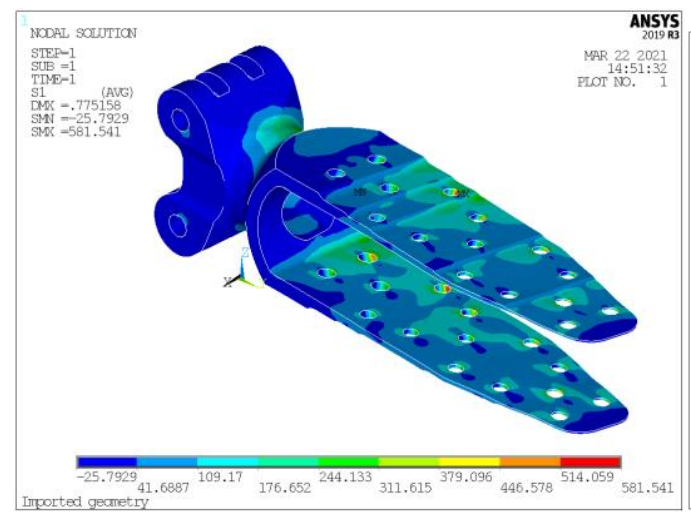

a

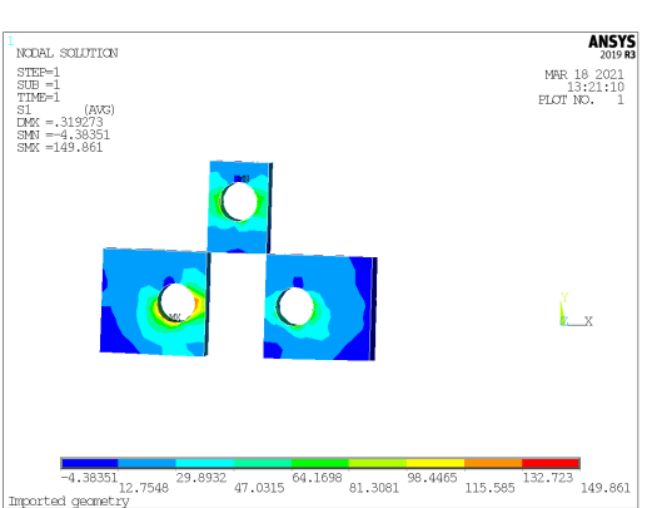

б

Рис 31. Поле распределения главных растягивающих напряжений а - в наконечнике лопасти; б - в зоне расположения группы отверстий $\varnothing 16$ мм (вид на нижний язычок наконечника изнутри)

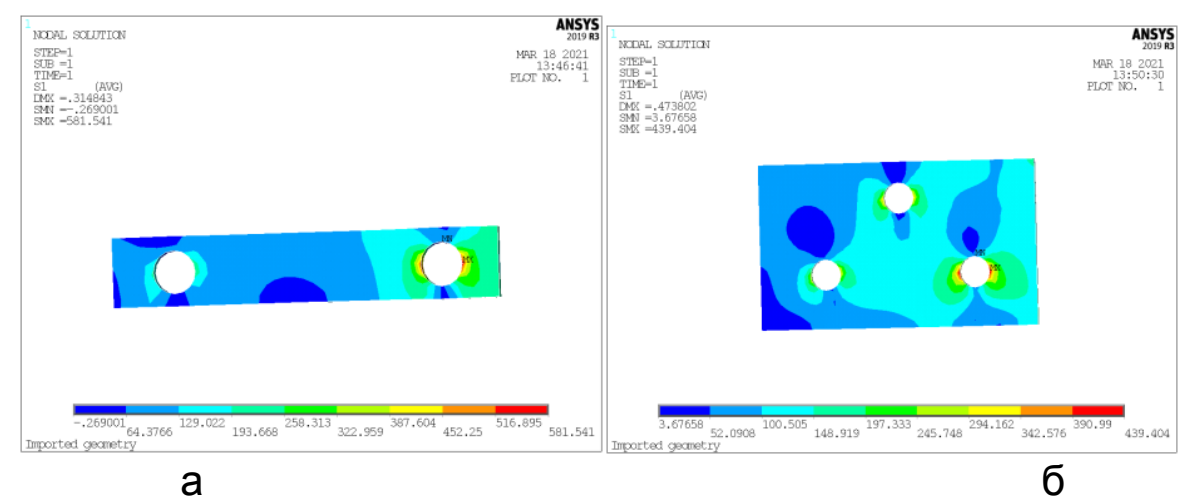

Рис 32. Поле распределения главных растягивающих напряжений в наконечнике лопасти: а - в зоне первого ряда отверстий $\varnothing 14$ мм;

б - в зоне второго ряда отверстий $\varnothing 14$ мм 


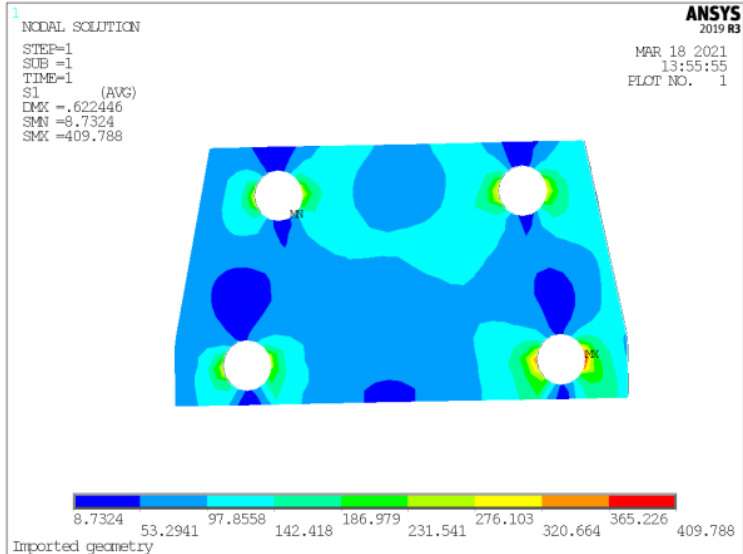

a

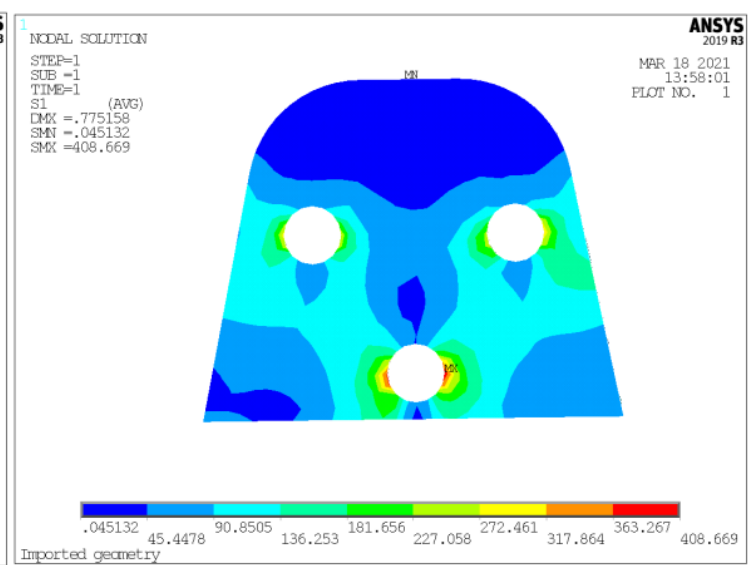

6

Рис 33. Поле распределения главных растягивающих напряжений в наконечнике лопасти: а - в зоне третьего и четвертого ряда отверстий $\varnothing 14$ мм; б - в зоне пятого ряда отверстий $\varnothing 14$ мм

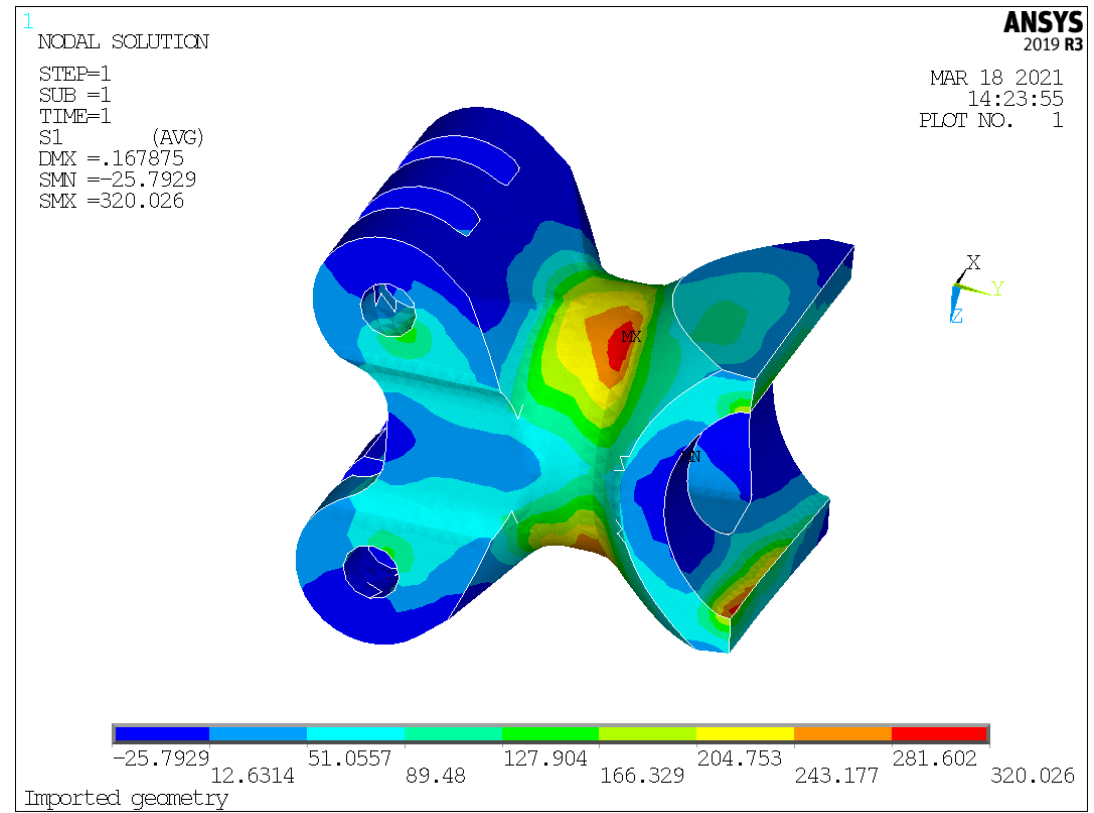

Рис 34. Поле распределения главных растягивающих напряжений в наконечнике лопасти в зоне вилки

Анализируя полученный результат, можно сделать вывод, что уровень максимальных главных растягивающих напряжений для всех типовых зон концентрации напряжений в наконечнике, кроме зоны крайнего отверстия, не превышает предела выносливости материала наконечника $\sigma_{-1}=519 \mathrm{MПа}$. В зоне крайнего отверстия максимальное значение напряжений достигает $\sigma_{1}=581,5 \mathrm{M \Pi a}$.

\section{Выводы}

1. Лопасть вертолета представляет собой сложное изделие в конструктивно-технологическом отношении, в котором используются многие материалы, виды обработки, контроля и испытаний. 
2. Тип базового технологического процесса, выбранного для производства лопастей, оказывает большое влияние на конструкцию лопастей, их прочность и стоимость.

3. Исследована комлевая часть лопасти несущего винта вертолета.

4. Построена геометрическая модель соединения в системе CATIA V5 и конечно-элементная модель комлевой части лопасти несущего винта в системе ANSYS.

5. Предложена модель упруго-деформируемого изотропного тела с заданием упругих констант материала для описания отклика материалов на внешнее воздействие.

6. Рассмотрен случай нагружения болтового соединения центробежной силой, возникающей при вращении лопасти.

7. Для моделирования контактного взаимодействия использовали обобщенную модель контактного взаимодействия типа «поверхность в поверхность».

8. Анализ результатов расчета включает в себя определение реакций в точках крепления, оценку величин максимальных перемещений элементов конструкции и напряжений в зонах концентрации напряжений.

9. Определены реакции в точках крепления наконечника по отверстиям в проушинах.

10. Проанализирован характер деформирования болтового соединения в целом и ее отдельных элементов.

11. Проведена оценка суммарных перемещений и компонентов перемещений.

12. Для оценки статической и усталостной прочности элементов болтового соединения наконечника с лонжероном лопасти проанализированы напряжения в силовых элементах по типовым концентраторам.

13. При оценке статической прочности анализировали распределение эквивалентных напряжений по Мизесу. Проанализировано распределение напряжений в зоне отверстий по рядам, начиная от корневого сечения в сторону увеличения координаты Ү. Максимальные значения напряжений по Мизесу для типовых зон концентрации напряжений сравнивали с пределом прочности материала элемента конструкции.

14. Для оценки усталостной прочности анализировали распределение главных растягивающих напряжений в силовых элементах по типовым концентраторам напряжений. Максимальные значения этих напряжений сравнивали с пределом выносливости материала конструктивного элемента.

\section{Список литературы}

1. Интегрированное проектирование винтокрылых летательных аппаратов транспортной категории [Текст]: учебник: в 3 ч. / А. Г. Гребеников, Н. И. Москаленко, В. А. Урбанович и др. - Х.: Нац. аэрокосм. ун-т им. Н. Е. Жуковского «Харьк. авиац. ин-т», 2016. - Ч. 1. - 411 с.

2. Проектування важких одногвинтових вертольотів та їх трансмісій. Ч. 1 [Електронний ресурс]: підручник / О.Г.Гребеніков, А.М. Гуменний, А. І. Долматов та ін. - Харків: Нац. аерокосм. ун-т ім. М. Є. Жуковського "Харків. авіац. ін-т", 2018. - 361 с.

3. Конструирование агрегатов и систем вертолётов: учеб. пособие /
К. Ю. Вишняков,
В. Н. Доценко,
Я. С. Карпов,
В. С. Кривцов,
Л. И. Лосев, 
В. И. Рябков, В. А. Урбанович. - Харьков: Нац. аэрокосм. ун-т «Харьк. авиац. ин-т», 2005. - 384 C.

4. Вертолет Ми-8 /В. А. Данилов, А. Г. Другов, И. В. Тетерин. - М.: Транспорт, 1979. - 248 с.

5. Методология интегрированного проектирования и моделирования сборных самолетных конструкций /А. Г. Гребеников. - Харьков: Нац. аэрокосм. ун-т «ХАИ», 2006. - 532 с.

6. ANSYS Analysis Guide. Structural Analysis Guide. Chapter 8. Nonlinear structural analysis. 001087. 4th Edition. SAS IP(C.

7. ANSYS Theory Manual. Chapter 2. Structures. SubSection 2.1.1. StressStrain Relationships. 001087. 4th Edition SAS IP @. - 2016.

8. ANSYS Contact Technology Guide. Chapter 10. Multipoint Constraints and Asseblies. Section 10.3. Surface-Based Constraints. 001087. 4th Edition SAS IP (C). 2016.

9. ANSYS Element Guide. Chapter 3. Element References. Section 3.1. Element Library. SOLID185. 001087. 4th Edition. SAS IPC. - 2016.

10. ANSYS Element Guide. Chapter 3. Element References. Section 3.1. Element Library. TARGE170 and CONTA174. 001087. 4th Edition. SAS IP@. - 2016.

11. ANSYS Contact Technology Guide. Chapter 3. Surface-to-Surface Contact. 001087. 4th Edition. SAS IPC.-2016.

References

1. Grebenikov, A.G., Moskalenko N.I., Urbanovich V.A. Integrirovannoe proektirovanie vintokrylyh letatel'nyh apparatov transportnoj kategorii: uchebnik $\vee 3$ ch. [Integrated design of rotary-wing aircraft transport category]. Khakov. Zhukovsky National Aerospace University, Kharkiv Aviation Institute. Publ., 2016, part1, 411 p.

2. Grebenikov, A.G., Humenny A.M., Dolmatov A.I. and oth. Proektuvannya vazhkih odnogvintovih vertoletiv ta in transmisiy: pidruchnik [Design of heavy singlerotor helicopters and their transmissions]. Khakov. Zhukovsky National Aerospace University, Kharkiv Aviation Institute. Publ., 2018, part1, 361 p.

3. Vishnyakov, K. Yu., Dotsenko, V. N., Karpov, Ya. S., Krivtsov, V. S., Losev, L. I., Ryabkov, V. I., Urbanovich, V. A. Konstruirovanie agregatov i sistem vertolyotov: ucheb. posobie [Design of the Helicopters Units and Systems]. Kharkov. National Aerospace University «Kharkiv Aviation Institute», Publ., 2005. - 384 p.

4. Danilov V.A., Druhov A.G., Teterin I.V. Vertolet Mi-8 [Helicopter Mi-8]. Moscow. Transport, Publ., 1979. - 248 p.

5. Grebenikov, A.G. Metodologiya integrirovannogo proektirovaniya i modelirovaniya sbornih samoletnih konstrurziy [Methodology for Integrated Design and Modeling of Prefabricated Aircraft Structures]. Kharkov. National Aerospace University «Kharkiv Aviation Institute», Publ., 2006. - 532 p.

6. ANSYS Analysis Guide. Structural Analysis Guide. Chapter 8. Nonlinear structural analysis. 001087. 4th Edition. SAS IP@).

7. ANSYS Theory Manual. Chapter 2. Structures. SubSection 2.1.1. StressStrain Relationships. 001087. 4th Edition SAS IP (C). - 2016.

8. ANSYS Contact Technology Guide. Chapter 10. Multipoint Constraints and Asseblies. Section 10.3. Surface-Based Constraints. 001087. 4th Edition SAS IP @ . 2016.

9. ANSYS Element Guide. Chapter 3. Element References. Section 3.1. Element Library. SOLID185. 001087. 4th Edition. SAS IP@. - 2016. 
10. ANSYS Element Guide. Chapter 3. Element References. Section 3.1. Element Library. TARGE170 and CONTA174. 001087. 4th Edition. SAS IPC. - 2016.

11. ANSYS Contact Technology Guide. Chapter 3. Surface-to-Surface Contact. 001087. 4th Edition. SAS IP@.-2016.

Поступила в редакцию 11.12.2020, рассмотрена на редколлегии 15.12.2020.

\section{Аналіз характеристик напружено-деформованого стану комлевої частини лопаті несучого гвинта вертольота}

Розглянуто комльову частину лопаті несучого гвинта (НГ) вертольота. Розроблено геометрична модель з'єднання, що розрахована за допомогою системи CATIA V5. За допомогою системи ANSYS розроблено скінченноелементну модель комлевої частини лопаті несучого гвинта, проведено розрахунок і аналіз характеристик отриманих результатів. Для опису відклику матеріалів на зовнішній вплив застосовували модель пружно-деформованого изотропного тіла із завданням відповідних пружних констант матеріалу. Розглянуто випадок навантаження болтового з'єднання відцентровою силою, що виникає при обертанні лопаті. Для моделювання контактної взаємодії приймали узагальнену модель контактної взаємодії типу «поверхню в поверхню». Аналіз результатів розрахунку містить визначення реакцій в точках кріплення, величин максимальних переміщень елементів конструкції і напруг у зонах концентрації напружень. У ході розрахунку визначено реакції в точках кріплення наконечника по отворах у вушках. Проаналізовано характер деформування болтового з'єднання в цілому та їі окремих елементів. Проведено оцінку сумарних переміщень і компонентів переміщень. Для оцінки статичної і втомної міцності елементів болтового з'єднання наконечника 3 лонжероном лопаті проаналізовано напруження в силових елементах за типовими концентраторами. Для оцінки статичної міцності аналізували розподіл еквівалентних напружень за Мизесом. Проаналізовано розподіл напружень у зоні отворів по рядах, починаючи від кореневого перетину в бік збільшення координати Y. Максимальні значення напруження за Мизесом для типових зон концентрації напружень порівнювали з межею міцності матеріалу елемента конструкції. Для оцінки втомної міцності аналізували розподіл головних напружень, що розтягують у силових елементах за типовими концентраторами напружень. Максимальні значення цих напружень порівнювали 3 межею витривалості матеріалу конструктивного елемента.

Ключові слова: лопать гвинта, комлева частина, геометрична модель, скінченно-елементна модель, болтове з'єднання, модель контактної взаємодії, статична міцність, втомна міцність.

\section{Analysis of the characteristics of the stress-strain state of the butt part of the main rotor blade of a helicopter}

The butt part of the main rotor blade $(R B)$ of the helicopter is presented. $A$ geometric model of the calculated connection was developed using the CATIA V5 system. With the help of the ANSYS system, a finite element model of the butt part of the main rotor blade was developed, and the calculation and analysis of the characteristics of the results obtained were carried out. To describe the response of materials to an external action, a model of an elastically deformable isotropic body 
was used with the assignment of the corresponding elastic constants of the material. The case of loading a bolted joint by a centrifugal force arising during the rotation of a blade is considered. To model the contact interaction, a generalized surface-tosurface contact interaction model was adopted. The analysis of the calculation results includes the determination of reactions at the attachment points, the values of the maximum displacements of structural elements and stresses in the stress concentration zones. In the course of the calculation, reactions were determined at the points of attachment of the tip along the holes in the lugs. The nature of the deformation of the bolted joint as a whole and of its individual elements is analyzed. The assessment of total displacements and displacement components is carried out. To assess the static and fatigue strength of the elements of the bolted connection of the tip with the blade spar, the stresses in the load-bearing elements were analyzed for typical concentrators. When assessing the static strength, the distribution of equivalent stresses according to Mises was analyzed. The distribution of stresses in the zone of holes along the rows is analyzed, starting from the root section in the direction of increasing the $Y$ coordinate. The maximum von Mises stresses for typical stress concentration zones were compared with the ultimate strength of the structural element material. To assess the fatigue strength, we analyzed the distribution of the main tensile stresses in the load-bearing elements by typical stress concentrators. The maximum values of these stresses were compared with the fatigue limit of the structural element material.

Keywords: main rotor blade, butt part, geometric model, finite element model, bolted connection, contact interaction model, static strength, fatigue strength.

\section{Сведения об авторах:}

Гребеников Александр Григорьевич - доктор технических наук, профрессор, зав. каф. 103 «Проектирование самолетов и вертолетов» Национального аэрокосмического университета им. Н.Е. Жуковского «Харьковский авиационный институт», Украина,

e-mail: agrebenikov@khai.edu

Малков Игорь Владиславович - доктор технических наук, профрессор, профессор каф. 103 «Проектирование самолетов и вертолетов» Национального аэрокосмического университета им. Н.Е. Жуковского «Харьковский авиационный институт», Украина, e-mail: i.malkov@khai.edu

Урбанович Владимир Антонович - доцент каф. 103 «Проектирование самолетов и вертолетов» Национального аэрокосмического университета им. Н.Е. Жуковского «Харьковский авиационный институт», Украина, e-mail: urb vl@ukr.net

Светличный Сергей Петрович - доцент каф. 202 «Национального аэрокосмического университета им. Н.Е. Жуковского «Харьковский авиационный институт», Украина

Лоленко Андрей Владимирович - главный конструктор КБ «Компьютерное проектирование» ХГАПП, Харьков, Украина

Кривобок Александр Иванович - главный конструктор КБ «Крыло» ХГАПП, Харьков, Украина

Москаленко Николай Иванович - главный конструктор, начальник управления по разработке и модификации вертолетной техники ОКБ «Мотор Сич», Запорожье, Украина 